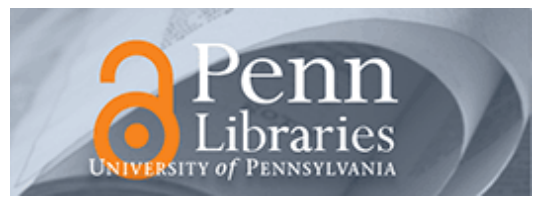

University of Pennsylvania

ScholarlyCommons

Accounting Papers

Wharton Faculty Research

$12-2013$

\title{
The Efficacy of Shareholder Voting: Evidence From Equity Compensation Plans
}

Christopher S. Armstrong

University of Pennsylvania

Ian D. Gow

David F. Larcker

Follow this and additional works at: https://repository.upenn.edu/accounting_papers

Part of the Accounting Commons

\section{Recommended Citation}

Armstrong, C. S., Gow, I. D., \& Larcker, D. F. (2013). The Efficacy of Shareholder Voting: Evidence From Equity Compensation Plans. Journal of Accounting Research, 51 (5), 909-950. http://dx.doi.org/10.1111/ 1475-679X.12023

This paper is posted at ScholarlyCommons. https://repository.upenn.edu/accounting_papers/67

For more information, please contact repository@pobox.upenn.edu. 


\title{
The Efficacy of Shareholder Voting: Evidence From Equity Compensation Plans
}

\begin{abstract}
This study examines the effects of shareholder support for equity compensation plans on subsequent CEO compensation. Using cross-sectional regression, instrumental variable, and regression discontinuity research designs, we find little evidence that either lower shareholder voting support for, or outright rejection of, proposed equity compensation plans leads to decreases in the level or composition of future CEO incentive compensation. We also find that, in cases where the equity compensation plan is rejected by shareholders, firms are more likely to propose, and shareholders are more likely to approve, a plan the following year. Our results suggest that shareholder votes for equity pay plans have little substantive impact on firms' incentive compensation policies. Thus, recent regulatory efforts aimed at strengthening shareholder voting rights, particularly in the context of executive compensation, may have limited effect on firms' compensation policies.
\end{abstract}

\section{Keywords}

executive compensation, equity-based compensation, shareholder voting

Disciplines

Accounting 


\title{
The Efficacy of Shareholder Voting: Evidence from Equity Compensation Plans
}

\author{
Christopher S. Armstrong \\ The Wharton School \\ University of Pennsylvania \\ carms@wharton.upenn.edu \\ Ian D. Gow \\ Harvard Business School \\ igow@hbs.edu \\ David F. Larcker \\ Graduate School of Business \\ Rock Center for Corporate Governance \\ Stanford University \\ larcker_david@gsb.stanford.edu
}

Draft: March 13, 2012

\begin{abstract}
This study examines the effects of shareholder support for equity compensation plans on subsequent chief executive officer (CEO) compensation. Using cross-sectional regression, instrumental variable, and regression discontinuity research designs, we find little evidence that either lower shareholder voting support for, or outright rejection of, proposed equity compensation plans leads to decreases in the level or composition of future CEO incentivecompensation. We also find that in cases where the equity compensation plan is rejected by shareholders, firms are more likely to propose, and shareholders are more likely to approve, a plan the following year. Our results suggest that shareholder votes have little substantive impact on firms' incentive-compensation policies. Thus, recent regulatory efforts aimed at strengthening shareholder voting rights, particularly in the context of executive compensation, may have limited effect on firms' compensation policies.
\end{abstract}

JEL Classification: G3; J33; M52

Keywords: executive compensation; equity-based compensation; shareholder voting

This paper has benefitted from comments from Richard Frankel, Sudarshan Jayaraman, and workshop participants at Cornell University, Dartmouth University, Harvard Business School, the University of Pennsylvania (Wharton), and Washington University. We thank Balfe Morrison for excellent research assistance. Larcker is grateful for financial support from the Joseph and Laurie Lacob Faculty Fellow Award. 


\section{Introduction}

Enhancing shareholders' ability to influence corporate policy has been the focus of several recent efforts to reform corporate governance, such as requirements for binding votes on stock-based compensation plans, mandatory reporting of mutual fund voting, "vote-no" campaigns, calls for elimination of broker non-votes, and legislation requiring advisory "say on pay" votes and proxy access. Much of this regulatory activity and debate is predicated on the notion that shareholder voting actually influences corporate behavior (e.g., Dodd-Frank Wall Street Reform and Consumer Protection Act). Although shareholder voting has been the subject of some prior research (e.g., Cai, Garner, and Walkling, 2009; Choi, Fisch, and Kahan, 2011), the effectiveness of shareholder voting as a mechanism to effect changes in corporate policy remains an open and controversial question.

The purpose of this paper is to examine the efficacy of shareholder voting in effecting changes in corporate policy. We focus on the effects of shareholder voting on equity-based compensation plans on firms' executive compensation policies for two reasons. First, equity compensation plans are widespread and require shareholder approval, making votes on these plans the most common subject of shareholder voting after director elections and auditor ratification. Second, equity compensation proposals attract much higher levels of shareholder disapproval than most other company-sponsored proposals that are put to shareholder vote (e.g., director elections and auditor ratification nearly always receive in excess of $90 \%$ shareholder support), making them a more powerful setting for empirical analysis. Of the 619 managementsponsored proposals rejected by shareholders between 2001 and 2010, $183(30 \%)$ related to 
equity compensation plans. ${ }^{1}$ For the 2,659 management-sponsored proposals where Institutional Shareholder Services (ISS), a leading proxy advisory firm, recommended a vote against the proposal, $1,719(65 \%)$ related to equity compensation plans. Moreover, ISS recommended against 27\% of the 6,270 equity compensation plans considered between 2001 and 2010 . Although only $2 \%$ of equity compensation proposals fail to receive the required level of shareholder support, this is substantially larger than the $0.07 \%$ failure rate for director elections, which have received considerably greater attention in recent research on shareholder voting and executive compensation. $^{2}$

Yermack $(2010,2.13)$ argues that "circumstantial evidence suggests that many firms have reacted to the rising tide of negative votes [for share authorization] by scaling back their equity compensation plans." However, there is little rigorous systematic evidence of such an effect. In this paper, we provide direct evidence on this issue by examining the effect of shareholder votes for, and the outright rejection of, equity pay plans on firms' executive compensation policies.

We first examine the determinants of shareholder support for proposed equity pay plans. In contrast to prior research that examines votes for individual directors (e.g., Cai et al., 2009; Fischer et al., 2009), shareholder sentiment regarding firms' executive compensation policies should be more directly reflected in their votes for equity pay plans. We find evidence that measures of "excess" compensation and shareholder dilution that are similar to those used by proxy advisors (e.g., ISS and Glass Lewis) and institutional investors (e.g., Fidelity Investments)

\footnotetext{
${ }^{1}$ Statistics based on data obtained from the ISS Voting Analytics database.

${ }^{2}$ Shareholders rejected $1.3 \%$ of management-sponsored proposals that do not relate to equity compensation plans during our sample period from 2001 to 2010 .
} 
are negatively related to shareholder support for equity compensation plans. ${ }^{3}$ However, these same measures have no association with shareholder support in director elections that occur at the same annual meeting. These findings suggest that shareholder voting on equity pay plans is a more likely channel than director voting for shareholders to express their sentiment about firms' executive compensation policies.

We then examine whether shareholder support for equity pay plans has an impact on firms' future compensation policies. This analysis is complicated because it is difficult to determine a priori the precise timing or elements of future compensation that should be affected by shareholder voting. Accordingly, we examine a variety of compensation measures over different horizons. In general, we find little evidence that shareholder voting support for equity pay plans affects future CEO compensation. Moreover, although not the primary focus of our paper, we do not observe a positive association between shareholder support in director elections and future compensation.

Given the endogenous nature of the relationship between shareholder voting support and CEO compensation, we supplement our cross-sectional regressions with two alternative research designs. First we employ instrumental variable (IV) regressions using ISS voting recommendations as an instrument for shareholder support. Given ISS's expressed policy of formulating its recommendation from a limited information set based on proxy filings made before shareholders vote, we argue that these recommendations provide a plausible source of exogenous variation in shareholder votes. ${ }^{4}$ Consistent with the results of our cross-sectional

\footnotetext{
${ }^{3}$ For discussion of the policies of ISS, Fidelity Investments, and other proxy advisors and institutional investors, see http://www.riskmetrics.com/sites/default/files/RMGExplorationsPayEquityCompensationPlans20080520.pdf (accessed November 14, 2010).

${ }^{4}$ The validity of this instrument depends on ISS recommendations not having an influence on future compensation decisions conditional on shareholder support (i.e., that firms listen to their shareholders, with ISS having only an
} 
regression analysis, the IV estimates also indicate that there is no relation between shareholder voting on compensation proposals and subsequent changes in CEO compensation.

Our second approach for addressing endogeneity is regression discontinuity design (RDD), which exploits the discrete nature of the level of voting support required for approval of an equity compensation plan (typically 50\%). With relatively minor assumptions, RDD allows us to estimate an unbiased treatment effect, even when the shareholder voting is jointly determined with future compensation outcomes. Since these proposals are formally binding, they provide a more powerful setting for observing the effects, if any, of shareholder rejection of companysponsored proposals. However, consistent with our earlier findings, the results from our RDD analysis provide virtually no evidence that failing to receive shareholder approval for an equity pay plan has an effect on subsequent executive compensation.

Given that shareholder votes on equity pay plans are binding in the sense that a failed vote deprives boards of the ability to grant the requested shares for compensation purposes, the lack of an effect on future equity-based compensation is puzzling. One possible explanation is that management responds to the rejection of a proposed equity pay plan by requesting additional shares in the subsequent year. To the extent that shareholders approve such requests, the total effect of shareholder rejection on equity-based compensation may be negligible. We examine this possibility and find that firms whose plans are rejected by shareholders are significantly more likely to request shares in the subsequent year. However, we find that the level of shareholder approval for these follow-up requests is not related to whether the original request was approved. This finding highlights the need to examine executive compensation and

indirect impact on corporate policies through their influence on shareholders' voting decisions). To the extent this condition does not hold, the traditional exclusion restriction that is required for instrumental variable estimation is invalid. As we discuss in more detail below, we assess the sensitivity of our IV inferences to relaxing this exclusion assumption. 
shareholder voting over multiple periods, as even if shareholder voting had an immediate effect, it might have little or no long-term effect.

Collectively, our findings are at odds with those of prior research, as they suggest that shareholder sentiment expressed through voting support does not affect firms' executive compensation policies. Our findings also suggest that recent regulatory efforts, which focus on strengthening shareholders' ability to affect corporate policy through shareholder voting, particularly in the context of executive compensation, may not have the desired effect on firm policies.

\section{Prior research}

\section{A. Voting and executive compensation}

This study is related to two papers that examine shareholder votes on equity compensation plans. Morgan, Poulsen, and Wolf (2006) examine aggregate shareholder votes for S\&P 500 firms from 1992 to 2003 and find evidence that shareholders provide less support for plans that are more dilutive and plans that receive negative recommendations from a proxy advisor. However, the focus of that paper differs from ours, as Morgan et al. (2006) do not examine the consequences of shareholder voting and shareholder approval of equity pay plans was not mandatory during their sample period. Martin and Thomas (2005) examine stock price reactions to management-sponsored executive-only stock option plans and find a negative reaction to plans with higher levels of potential dilution. Martin and Thomas (2005) also examine the effect of voting outcomes on subsequent compensation and find evidence consistent with directors responding to negative shareholder votes by reducing future executive compensation. However, they find no association between shareholder support for stock option plans and future stock option grants. 
Several recent studies have examined the effect of other types of shareholder voting on various aspects of firms' executive compensation policies. For example, Fischer et al. (2009) examine the effect of shareholder support for the board and CEO in uncontested director elections on compensation. They find evidence of a positive relation between future excess compensation and shareholder support for CEOs standing for election, but no statistically significant relation when shareholder support is measured as the median ratio of votes "for" to total votes cast across all directors standing for election. Cai, Garner, and Walkling (2009) also focus on uncontested director elections and find that, for firms with positive abnormal CEO compensation in the year of the vote, future abnormal CEO compensation is decreasing in the level of shareholder support for directors that serve on the compensation committee. However, this association does not hold for directors in general or for directors that are not members of the compensation committee. In addition, Cai et al. (2009) find a negative relation between shareholder support for directors and both subsequent CEO turnover and the removal of takeover protection mechanisms such as poison pills and classified boards. Collectively, prior research finds modest evidence of a positive relation between shareholder support and future CEO compensation.

In August 2002, the United Kingdom (UK) introduced the Directors' Remuneration Report Regulations 2002, which require publicly traded UK firms to include an executive pay report in their annual filing and to submit this report to a shareholder vote at the annual meeting (similar to say-on-pay votes required under recent US legislation, these votes are advisory rather than binding). Two recent papers examine the effects of these regulations. Ferri and Maber (2011) find that firms that receive low levels of shareholder support are more likely to amend their executives' compensation contracts in ways that are viewed as more "shareholder friendly" 
(e.g., removing or reducing severance payments). Carter and Zamora (2009) examine the determinants of shareholder support in say-on-pay votes and find evidence that higher levels of dilution from equity compensation are associated with lower levels of shareholder support. They also examine the consequences of low shareholder support and find modest evidence of a negative relation between shareholder support and future CEO pay.

In the US, Section 951 of the Dodd-Frank Wall Street Reform and Consumer Protection Act (Pub. L. 111-203, H.R. 4173, the "Act") amended the Securities Exchange Act of 1934 to require companies subject to the federal proxy rules to provide shareholders with an advisory vote on executive compensation. ${ }^{5}$ These votes are required at least once every three years beginning with the first annual shareholder meeting on or after January 21, 2011. Cai and Walkling (2009) study the passage of the Say-on-Pay Bill—from which the Dodd-Frank Act derives - by the US House of Representatives. They find that the firms that are most likely to benefit from such legislation have positive announcement-period stock returns. Larcker, Ormazabal, and Taylor (2011) apply an event study methodology to events leading up to the passage of say on pay and proxy access legislation and find evidence consistent with proxy access diminishing shareholder value. ${ }^{6}$

One important potential limitation of say on pay is that the result of the vote has no binding effect on the board. In contrast, if shareholders reject a proposed equity compensation plan, the board cannot issue the options or shares that would have been authorized under the new plan. Accordingly, if the primary role of the shareholder vote is to prevent actions from being taken, votes on equity compensation plans should have a greater impact on future compensation

\footnotetext{
${ }^{5}$ Section 971 of the Act also relates to shareholder voting. This section authorizes the SEC to issue rules permitting the use by a shareholder of proxy solicitation materials supplied by an issuer for the purpose of nominating directors. ${ }^{6}$ Prior to this legislation, very few US firms had voluntarily conducted say-on-pay votes in 2008 and 2009.
} 
than say-on-pay votes. ${ }^{7}$

\section{B. $\quad$ Effect of institutional shareholder activism}

Another stream of literature examines the efficacy of shareholder activism in effecting changes in corporate policy. Del Guercio, Seery, and Woidtke (2008) provide evidence that firms respond to campaigns by activist institutional investors to "just vote no" with operating performance improvements, greater CEO turnover, and governance changes. Bushee, Carter, and Gerakos (2010) find evidence that firms with a high level of ownership by governance-sensitive institutions exhibit significant future improvements in shareholder rights, consistent with an effect of shareholder activism. Morgan et al. (2010) examine mutual fund voting on shareholder proposals and find that greater support by funds leads to a greater likelihood of a proposal's passage and a greater likelihood of its subsequent implementation by management.

More closely related to our paper is Ertimur, Ferri, and Muslu (2010), who study "vote no" campaigns and shareholder proposals related to executive pay between 1997 and 2007. Ertimur et al. (2010) find that voting support for the proposal (i.e., lower support for management) is higher at firms with higher (excess) CEO pay. They also find that CEOs with excess pay who are targeted by vote-no campaigns receive lower future compensation.

This paper contributes to the literature on shareholder voting and corporate governance by examining a comprehensive sample of binding shareholder votes on management-sponsored executive compensation proposals. We examine a variety of compensation measures, whereas

\footnotetext{
${ }^{7}$ There are two potential differences between say-on-pay votes and votes for equity pay plans. The first potential difference is that say-on-pay votes allow shareholders to express their approval or dissatisfaction with the broad philosophy of executive compensation proposed by the board. In contrast, votes on equity pay plans may be narrowly construed as pertaining merely to the proposal at hand. The second potential difference derives from the non-binding nature of say-on-pay votes. Since shareholders can freely express their opinions without the possibility of direct adverse consequences (e.g., causing an undesirable equity pay plan to pass, or a desirable plan to fail), they can vote without concern for such consequences. In other words, say-on-pay votes may be less affected by strategic voting because of their advisory rather than binding nature.
} 
prior studies typically focus on one such outcome. Our focus on executive compensation also enables us to more clearly identify plausible consequences of shareholder voting. Finally, our focus on binding rather than advisory votes, such as those on shareholder proposals or say on pay, provides a setting in which shareholder voting should be more effective.

\section{Research Design}

A. Determinants of shareholder voting support for equity pay plans and directors

We first examine the determinants of shareholder voting support for equity pay plans and director elections. Given the recent emphasis on measures of dilution by ISS and major institutional investors, we also include two measures of the dilution associated with the proposed equity pay plan and the firm's historical equity compensation: Shares Requested, which equals the number of shares requested in the equity proposal divided by the number of shares outstanding as disclosed in the proxy statement; and Shares Available, which equals the number of shares and options available under existing plans as disclosed in the proxy divided by the number of shares outstanding. The sum of these measures may be viewed as a proxy for ISS's measure of dilution from an equity compensation plan which they refer to as shareholder value transfer (SVT). ${ }^{8}$

We also include the determinants of CEO incentive-compensation identified by prior

8 In their 2012 U.S. Proxy Voting Summary Guidelines (accessed on February 21, 2012 at http://www.issgovernance.com/files/2012USSummaryGuidelines1312012.pdf), ISS provides the following description of SVT: "SVT is expressed as both a dollar amount and as a percentage of market value, and includes the new shares proposed, shares available under existing plans, and shares granted but unexercised. The Shareholder Value Transfer is reasonable if it falls below the company-specific allowable cap. The allowable cap is determined as follows: The top quartile performers in each industry group (using the Global Industry Classification Standard: GICS) are identified. Benchmark SVT levels for each industry are established based on these top performers' historic SVT. Regression analyses are run on each industry group to identify the variables most strongly correlated to SVT. The benchmark industry SVT level is then adjusted upwards or downwards for the specific company by plugging the company-specific performance measures, size and cash compensation into the industry cap equations to arrive at the company's allowable cap." 
research (e.g., Core, Holthausen, and Larcker, 1999; Core, Guay, and Larcker, 2008), including the CEO's tenure, $\log \left(C E O\right.$ Tenure $\left._{t-1}\right)$; firm size measured as the natural logarithm of the firm's annual revenue, $\log \left(\right.$ Revenue $\left._{t-1}\right)$; the Book-to-market $t_{t-1}$ ratio to capture firms' growth opportunities; and the previous two years' accounting and stock returns, ROA and Stock Return, respectively. ${ }^{9}$ We also include the CEO's Comp Mix $x_{t-1}$, defined as one minus the ratio of salary to total annual compensation and $\log \left(\right.$ Total $\left.\operatorname{Comp}_{t-1}\right)$, defined as the natural logarithm of the CEO's total annual compensation during the last fiscal year ending prior to the meeting, as disclosed in the proxy filing for the meeting. These two variables measure the composition (or mix) and level, respectively, of CEOs' annual compensation. Because we include the determinants of "expected compensation" and its composition in the specification, the coefficients on $\log \left(\right.$ Total $\left.^{C o m p}{ }_{t-1}\right)$ and Comp Mix $t_{t-1}$ can be interpreted as the marginal effects of "excess compensation" (i.e., the level of compensation that is not explained by the determinants) and a relatively high proportion of equity-based pay, respectively, on shareholder voting support. To the extent shareholder voting support reflects their dissatisfaction with relatively high levels of CEO compensation or relatively high proportions of equity-based pay, we should observe a negative relation between these variables and shareholder support.

As discussed above, prior research regards shareholder support for directors and management-sponsored equity compensation proposals as a measure of shareholder approval of firms' compensation practices. Although several papers have focused on director elections (e.g., Cai et al., 2009; Fischer et al., 2009), we expect that the relations between the proxies for firms' compensation practices and shareholder support for equity compensation proposals will be stronger than the relations between these proxies and shareholder support for directors up for

\footnotetext{
${ }^{9}$ Our specification is broadly consistent with that of Cai, Garner, and Walkling (2009), who regress director election votes on prior-year industry-adjusted EBITDA and excess stock return.
} 
election. Finally, to allow for the possibility that proxies for firms' compensation practices affect shareholder support for equity pay proposals only through their effect on shareholder support for directors, and vice versa, we also estimate specifications that control for the other measure of shareholder support.

\section{B. $\quad$ Future compensation: Cross-sectional regression analysis}

Our first set of analyses is based on a research design that is similar to that used in most of the prior research. In particular, we model a variety of incentive-compensation variables as a function of shareholder support for equity pay plans. However, unlike prior research (e.g., Fischer et al., 2009), we use the raw values of the incentive-compensation variables as our dependent variables and we include a variety of independent variables to control for both the determinants of the shareholder vote and the expected incentive-compensation variables. ${ }^{10} \mathrm{We}$ also include the lagged value of the respective dependent variable in the year prior to the vote (e.g., when modeling the effect of shareholder votes on future total CEO compensation, we include total CEO compensation for the year ending prior to the year of the vote). Inclusion of the lagged value of the dependent variable means that the coefficient on shareholder support captures primarily time-series (i.e., within-firm), rather than cross-sectional, variation in the dependent variable (e.g., future CEO compensation). This research design choice more closely aligns with the notion of shareholder votes affecting changes in firms' policies, which predicts time-series, rather than cross-sectional variation in the level of future CEO compensation.

Finally, since executive compensation contracting is complex and often involves both explicit and implicit contracts over multiple periods, it is unclear when to expect the effect of a shareholder vote to manifest in compensation. Therefore, we model the incentive-compensation

\footnotetext{
${ }^{10}$ As should be expected given our inclusion of standard determinants of compensation in our regressions, we get similar inferences throughout if we use excess compensation as the dependent variable.
} 
variables over three different horizons: the fiscal year that includes the shareholder meeting at which the vote occurs (labeled year $t$ ) and each of the two successive fiscal years (labeled years $t$ +1 and $t+2$, respectively).

\section{Future compensation: Instrumental variable analysis}

One concern with our panel regressions (and similar research designs used in prior studies) is that one cannot draw causal inferences about effect of shareholder voting on firms' compensation policies because of the endogenous nature of shareholder voting with respect to firms' compensation policies. In particular, it is easy to conceive of ways in which the error term in regressions of future compensation could be correlated with the main regressor of interest, shareholder support. For example, if shareholders' information set includes insight into future compensation levels that is unexplained by included controls and if shareholders provide lower voting support when they anticipate higher levels of future compensation, then the estimated coefficient on shareholder support will be biased downward (i.e., lower shareholder support will be associated with higher future compensation levels). We attempt to alleviate concerns about this form of endogeneity using instrumental variables estimation.

We instrument for shareholder support with ISS For Pay Plan, an indicator for whether the compensation proposal put forth received a favorable recommendation from ISS. The decision model of ISS, as extensively documented in ISS policy documents, is largely based on historical compensation data, all of which are obtained exclusively from proxy filings issued prior to the relevant meeting. In the terminology of Pearl (2000) and Morgan and Winship (2007), ISS For Pay Plan may eliminate the confounding effect of the "back-door path" running from shareholders' information about future compensation that is not reflected in the current 
proxy filings to shareholder voting. ${ }^{11}$ The exclusion restriction implied by our use of ISS For Pay Plan as an instrument for shareholder support is that firms do not respond directly to ISS recommendations by altering future compensation packages, but only indirectly, with shareholder support mediating the effect of ISS recommendations. ${ }^{12}$ As we discuss in more detail below, we assess the sensitivity of our instrumental variables estimates to relaxing the traditional assumption that the exclusion restriction is exactly satisfied.

\section{Future compensation: Regression discontinuity design}

We also supplement our instrumental variables analysis with an alternative, and arguably superior, research design for identifying the causal effects of shareholder support for equity pay plans on firms' compensation policies. Rather than considering the level of shareholder voting support for an equity compensation plan as the treatment of interest, we instead consider failing to receive sufficient shareholder support as the treatment of interest for this analysis. Although failing a shareholder vote is a more narrow treatment in the sense that it relates to only a subset of equity pay plans, it provides a more powerful setting in which to identify the causal effects of shareholder voting support. In particular, as discussed by Lee (2008), regression discontinuity designs (RDDs) "involve a dichotomous treatment variable that is a deterministic function of a single, observed, continuous covariate." In the context of shareholder voting on equity compensation plans, whether the plan fails (the "treatment variable") is a deterministic function of the percentage of votes for the plan (i.e., if the percentage is below the cutoff, typically $50 \%$,

\footnotetext{
${ }^{11}$ If we could develop a proxy for shareholders' information about future compensation beyond what is captured by the control variables that we include in our specification, then including such a proxy would eliminate the "backdoor path" between shareholders' information and future incentive-compensation outcomes that would bias the estimated effect of shareholder voting. However, absent such a proxy, there is a correlated omitted variables problem and credible identification of a causal effect of shareholder voting requires a valid instrument that only affects future incentive-compensation indirectly through its effect on shareholder voting, and not through this possible "back-door path."

${ }_{12}$ Absent an effect on shareholder support, there appears to be no reason for firms to be concerned about ISS recommendations to institutional shareholders on how to vote shares.
} 
then the plan fails).

RDD has been used in voting settings in prior literature. For example, Lee (2008) examines the incumbency effect that results from winning elections in the US House of Representatives, a treatment assigned by receiving more than $50 \%$ of the vote. RDD has also been applied in the context of shareholder elections. Cuñat, Gine, and Guadalupe (2012) use RDD to examine the effect of governance changes related to shareholder proposals. Two issues with their setting are the heterogeneity of proposals (see Appendix A of Cuñat et al., 2012) and the differing motives of the shareholders making the proposals. Nonetheless, Cuñat et al. (2012) find evidence of a positive stock price reaction to the passage of a proposal, with stronger results when the analysis focuses on proposals related to shareholder rights of the kind examined by Gompers, Ishii, and Metrick (2003). Listokin (2009) uses RDD to examine the effect of dissidents' success in proxy fights on stock returns. One issue with this setting is that proxy fights are relatively rare events and Listokin's sample includes only 97 observations.

Although RDD is a powerful research design for identifying causal effects, one potential concern that can impair its validity is what is termed "manipulation of the running variable," which in our setting corresponds to firms "managing" shareholder voting to achieve $50 \%$ support. In particular, Listokin (2008) provides evidence of management's ability to sway close votes in its favor. Using a sample of 13,360 unique votes on management-sponsored proposals from 1997 through 2004 collected by Investor Responsibility Research Center (IRRC), Listokin (2008) finds 22 votes that receive between 47 and 50 percent support and 167 votes that receive between 50 and 53 percent support. We find a similar result for our sample (Panel A of Figure 1), which raises the possibility that non-random factors drive the assignment of firms around the $50 \%$ threshold. As we discuss in more detail below, management's ability to influence voting 
outcomes does not necessarily invalidate either our RDD analysis or the resulting estimates, as long as firms are unable to precisely manipulate voting results. Moreover, the fact that some equity pay proposals fail to receive sufficient shareholder support to pass the threshold suggests that although management may be able to exert some control over the outcome, they cannot precisely control the outcome.

\section{Sample, Data, and Descriptive Statistics}

\section{A. Sample selection}

We compile data on votes on stock-based compensation plans from two primary sources. The first source, Equilar Inc., provides data about the nature of plans proposed (e.g., stock option, restricted stock, or omnibus), whether the proposal relates to a new or an existing plan, the number of shares requested, and details on the votes for, votes against, and abstentions. ${ }^{13}$ Equilar provides data on 5,791 equity compensation plan proposals (excluding 968 stock purchase plans) submitted to shareholder vote between 2003 and 2010.

The second source, ISS Voting Analytics, provides information about matters voted on at shareholder meetings for 4,759 distinct companies over the period from 2001 to 2010, including details on the votes for, votes against, and abstentions for each proposal, the voting standard (typically $\geq 50 \%$ ), the voting base (i.e., shares voting on the proposal, shares voting or abstaining, or shares outstanding), whether the proposal passed or failed, and ISS's recommendation for shareholder voting.

We focus on votes on management-sponsored equity compensation proposals, for which ISS Voting Analytics provides 9,952 observations. Additional data requirements reduce our ISS

\footnotetext{
${ }^{13}$ Equilar is a provider of comprehensive executive compensation data, much of which is obtained from SEC filings.
} 
Voting Analytics sample to 9,735 observations and our Equilar sample to 5,767. ${ }^{14}$ The intersection of these two data sets yields our initial primary sample, which consists of 3,439 observations. For our RDD analyses, we require a precise measure of \% For Pay Plan, which requires correct specification of the voting base, a data item that is provided by ISS Voting Analytics, but not Equilar.

To maximize the power of our RDD analyses, which rely primarily on observations with voting outcomes close to the $50 \%$ threshold, we identify 180 observations from Equilar for which we lack data from ISS Voting Analytics, and that have voting support greater than $40 \%$ (using votes for and votes against as the voting base), but less than $60 \%$ (using votes for, votes against, and abstentions in the voting base). We hand-collect data from 203 proxy filings for these 180 observations. We define a "close vote" as one with voting support measured with the correct voting base, between $45 \%$ and 55\%. This hand-collection adds 131 observations (68 close votes) to the 9,499 (327 close votes) for which we have the necessary data from ISS Voting Analytics. Our total sample of close votes is 378 , and our total sample of votes is 9,420 .

\section{B. Measurement of compensation variables}

We examine a comprehensive set of CEO and company-wide incentive-compensation variables derived from compensation data from Equilar. The first four variables are related to the CEO's annual compensation and are (1) Cash Comp, defined as the natural logarithm of the sum of the CEO's annual salary and bonus payments, (2) Option Comp, defined as the natural logarithm of an adjusted Black-Scholes value for the CEO's annual option grants, (3) Total Comp, defined as the natural logarithm of the value of the CEO's total annual compensation (i.e., salary, bonus, restricted stock and option grants, and long-term incentive plan payouts), and (4)

\footnotetext{
${ }^{14}$ We lose 220 observations because ISS Voting Analytics does not include the data required to calculate \% For Pay
} Plan. 
Comp Mix, defined as one minus the ratio of salary to total annual compensation. ${ }^{15}$

We also examine Portfolio Delta, which measures the sensitivity of the CEO's equity portfolio value to changes in stock price. Core and Guay (1999) provide evidence that boards use restricted stock and option grants to adjust CEOs' equity portfolio delta to the desired "optimal" level. Consistent with prior literature (e.g., Core and Guay, 1999; Coles, Daniel, and Naveen, 2006; Burns and Kedia, 2006), we measure Portfolio Delta as the natural logarithm of the change in the risk-neutral (Black-Scholes) value of the CEO's equity portfolio for a $1 \%$ change in the firm's stock price.

We also examine CEO Turnover, an indicator for whether the CEO at the date of the shareholder meeting is no longer the CEO on the respective measurement date, since hiring and firing the CEO is one of the primary roles of the board, and termination can be a powerful incentive mechanism. Prior research (e.g., Engel, Hayes, and Wang, 2003) has documented a number of performance measures that are used by boards when making turnover decisions and it is reasonable to assume that shareholder support for equity pay plans may also be considered by directors when making their turnover decisions. Finally, since the effect of shareholder voting may not be confined solely to CEOs' incentive-compensation, we examine Options Granted, defined as the aggregate number of options granted to the firm's employees during the fiscal year scaled by the total number of shares outstanding at the beginning of the year. For example, if shareholder support reflects their opposition to the dilutive effects of a proposed equity pay plan,

\footnotetext{
${ }^{15}$ We calculate the risk-neutral value of a CEO's option grants and holdings using the Black-Scholes formula with the following parameters. Annualized volatility is calculated using continuously compounded monthly returns over the prior 36 months, requiring a minimum of 12 months. The risk-free rate is calculated using interpolated interest rate on a Treasury Note with the same maturity as the remaining life of the option multiplied by 0.7 to account for the prevalence of early exercise. Dividend yield is calculated as the dividends paid during the previous 12 months scaled by stock price at the beginning of the month. This is essentially the same method described by Core and Guay (2002).
} 
boards may respond to this concern by curtailing future firm-wide option grants rather than (or, perhaps, in addition to) future option grants to the CEO.

\section{C. $\quad$ Timing of incentive-compensation variable measurement}

Our tests require a choice of when compensation can be considered a future outcome relative to the meeting at which a shareholder vote occurred. Clearly compensation reported for the fiscal year ending prior to the proxy filing, which we label as year $t-1$, is not a future outcome relative to the meeting following the proxy filing. However, it is also unclear whether compensation for the fiscal year that includes the meeting date, which we label year $t$, is a future outcome. Fischer et al. (2009) focus on compensation for the first year beginning after the meeting date, which we label year $t+1$, due to concerns that compensation variables measured in year $t$ may not capture the board's response to shareholder votes in year $t$. However, it seems that for several compensation components (bonus is perhaps the clearest case), directors would have some latitude to make adjustments in the year of the vote in response to shareholder support from the votes at the meeting. Furthermore, to the extent that directors are concerned about their reputational capital, if they do not adjust compensation for year $t$, then shareholders will not observe the changes in compensation until the proxy for year $t+2$ is filed. ${ }^{16}$ However, some elements of compensation (salary is an obvious example) may be set by the time of the proxy filing and shareholder meeting, and thus should not be affected by the voting outcomes at the annual meeting. To accommodate ambiguity in the timing of the effects of shareholder voting on compensation, we examine incentive-compensation variables in both years $t$ and $t+1$. Additionally, to allow for the possibility that there is some lag in the effect of shareholder votes,

\footnotetext{
${ }^{16}$ This assumes that the proxy filing is the primary channel for firms to communicate information about executive compensation. We are not aware of any empirical evidence on firms' use of alternative channels to communicate information about executive compensation.
} 
we also examine compensation in year $t+2$ relative to the meeting date.

\section{Descriptive statistics}

Panel A of Table I presents the median values of the primary variables in our analysis according to the outcome of the vote on the equity pay plan. A visual comparison of the second and third columns (i.e., All Passing Votes and All Failing Votes, respectively) suggests that these firm-years differ along many dimensions, including their incentive compensation policies prior to the shareholder vote. A comparison of the last two columns (i.e., Close Passes and Close Fails, respectively) suggests that these two sets of firm-years are more similar along most dimensions, which is important for the validity of our subsequent RDD analysis.

Panel B of Table I reports the frequency of the different voting outcomes during each of our sample years. Although both failing votes and votes that closely fail (i.e., those that receive between $45 \%$ and $50 \%$ of the shareholder vote) are relatively rare, they are not confined to any particular subperiod of our ten-year sample period.

Panel C of Table I provides details on the sample derived from 24,784 firm-years provided by ISS Voting Analytics for matters put to shareholder votes in the years between 2001 and 2010 for 4,821 distinct firms. Of the 24,784 firm-years, 8,821 (35.6\%) include a vote on an equity compensation plan, which implies that a typical firm seeks shareholder approval of an equity compensation proposal approximately once every three years. However, there is wide variation in the frequency with which firms put forward equity compensation proposals. For the 4,759 firms in our sample, more than $70 \%$ put two or fewer equity compensation proposals to a vote during 2001-2010, but 152 firms have six or more plans considered. There are also three firms, CEC Entertainment, Electronic Arts, and Plantronics, Inc., that put forward an equity compensation plan each year during 2001-2010. 


\section{Results}

\section{A. Determinants of shareholder support}

Table II reports the results of our analysis of shareholder support for both equity compensation plans and directors in years in which equity compensation plans are put to a shareholder vote. The first two columns examine the relations between \% For Directors, the number of votes for a director divided by the sum of votes for that director and the votes withheld, and variables that capture firms' compensation practices and predictors of expected compensation. Regardless of whether shareholder support for equity compensation plans considered at the same meeting (i.e., \% For Pay Plan) is included in the analysis, we find little evidence that shareholders use votes on directors to express dissatisfaction with more dilutive equity pay plan proposals or higher CEO compensation. If anything, there is a positive, albeit weak, relationship between the dilution associated with the proposed equity pay plan and total CEO compensation and shareholder support for directors (coefficient on Shares Requested of $0.048, t$-stat. of 1.866).

The last two columns of Table II present results for \% For Pay Plan, the number of votes for the equity compensation proposal divided by the voting base, which varies by firm, but generally equals either the sum of votes for and votes against the proposal, or the sum of votes for, votes against, and abstentions. Inferences from both columns are identical, but we focus on the last column for brevity. In both columns, there is a clear negative relationship between shareholder support for the equity pay plan and the two measures of shareholder dilution, Shares Requested (coefficient of -0.561 and $t$-stat of -15.450 ) and Shares Available (coefficient of 0.367 and $t$-stat of -5.078), as well as Comp Mix $x_{t-1}$ (coefficient of -0.002 and $t$-stat of -6.623 ), which captures the proportion of annual CEO pay that is non-salary, and $\log \left(\right.$ Total $\operatorname{Comp}_{t-1}$ ) 
(coefficient of -0.006 and $t$-stat of -2.158 ), which, because of the other control variables, captures "excess" compensation. These results suggest that rather than "shareholders express[ing] their dissatisfaction [with executive compensation] by withholding votes for directors" (Cai, et al., 2009), a more important and direct channel though which shareholders express such dissatisfaction is their votes on equity compensation proposals. ${ }^{17}$

\section{B. Shareholder support for equity compensation plans and future compensation}

Prior research has argued that directors respond to lower levels of shareholder support by reducing future CEO compensation. For example, Fischer et al. (2009) examine the association between shareholder support in director elections, including elections in which the CEO is a director, and future excess compensation. They find weak evidence of a relation between some of their measures of shareholder support in director elections and future CEO compensation, but a stronger relation when they focus on elections involving the CEO. Similarly, Cai et al. (2009) examine the relation between shareholder support in director elections and future changes in excess compensation, but limit their analysis to the subsample of CEOs with positive "excess" compensation prior to the vote. They find significant relations when the director is a member of the compensation committee, but not for other members of the board or for all board members taken together. The lack of a result for all directors in both Cai et al. (2009) and Fischer et al. $\underline{(2009)}$ is consistent with our results in Table II, which suggest that shareholders' votes for directors is unlikely to be the most powerful or direct channel through which shareholders express their support for firms' compensation policies. For this reason, our primary analyses

\footnotetext{
${ }^{17}$ Note that our analysis is limited to director elections at meetings where equity compensation proposals are also considered. It may be that, absent such proposals, shareholders express their dissatisfaction through their votes in director elections.
} 
focus on shareholder votes on equity-based compensation plans. ${ }^{18}$

Table III reports the results of panel regressions of various compensation-related outcomes on shareholder voting support for equity pay plans (\% For Pay Plan) and directors (\% For Director). Panel A models contemporaneously measured (i.e., year $t$ ) incentivecompensation variables and the results reveal that there is a strong negative relation between shareholder support for the pay plan in four of the seven specifications: Option Comp

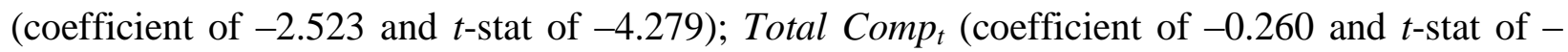

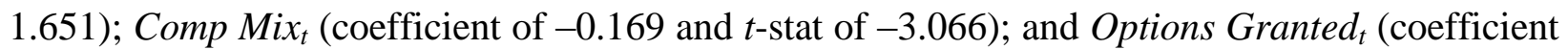
of -0.013 and $t$-stat of -7.640). The exceptions are Cash Comp t $_{t}$ and Portfolio Delta , for which the relations are negative, but insignificant. In addition, director support is insignificant in every specification except Option Comp of -1.511 and $t$-stat of -1.829$)$. Because the outcome variables in Panel A are measured during the fiscal year that includes the meeting date, these results are consistent with shareholders observing relatively high levels of CEO incentive compensation, or high levels of aggregate options grants, and responding with lower support for the equity pay plan. ${ }^{19}$

Panels B and C of Table III model the one- and two-year-ahead incentive-compensation variables, respectively. Similar to the results in Panel A, we find that shareholder support for the

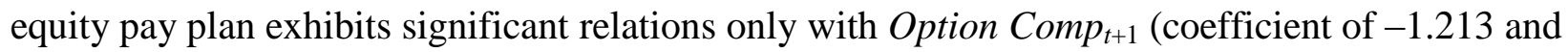
$t$-stat of -2.057) and Comp Mix $x_{t+1}$ (coefficient of -0.151 and $t$-stat of -4.592 ). However, unlike the specifications in Panel A, the dependent variables in Panels B and C are unambiguously

\footnotetext{
${ }^{18}$ Nonetheless, given the focus of prior research on director elections, we also examine shareholder support in director elections (both those that occur at shareholder meetings at which there is vote on an equity compensation plan and those at which there is not) in Table VII. We find virtually no evidence to support the hypothesized positive relation between future compensation and shareholder votes for directors.

${ }^{19}$ Recall that because these specifications include both the lagged value of the dependent variable and additional determinants as control variables, they can be viewed as models of changes in annual "excess" incentivecompensation and "excess" aggregate option grants.
} 
measured after the shareholder meeting at which the vote occurs. Therefore, if directors respond to less favorable shareholder sentiment as expressed in their votes on equity compensation plans by reducing future compensation, then the effect should manifest in positive coefficients on $\%$ For Pay Plan in the regressions presented in Panels B and C of Table III. The absence of positive coefficients across the various specifications in these panels is inconsistent with findings of prior literature (e.g., Cai et al., 2009; Fischer et al., 2009, which find modest evidence of a positive relation between shareholder support and future CEO compensation) and is at odds with the notion that directors respond to shareholder voting support for pay plans and directors.

\section{Instrumental variable analysis}

As discussed above, one explanation for negative or insignificant coefficients is the potential endogeneity if shareholder support reflects shareholders' expectations about future compensation that is not captured by the variables included in the regression analyses in Table III. To address this possibility, we estimate instrumental variable regressions of various oneyear-ahead (i.e., year $t+1$ ) incentive-compensation variables on shareholder voting support for equity compensation plans (\% For Pay Plan) using ISS's voting recommendation (ISS For Pay Plan) as the instrument for shareholder support. To the extent that ISS formulates its voting recommendations for equity pay plans as a mechanical (and therefore, somewhat arbitrary) function of historical financial and compensation variables, it will produce variation in shareholder support for equity pay plans that is exogenous with respect to future incentivecompensation.

The estimates from our instrumental variables specification in Table IV provide little evidence that shareholder support for equity pay plans is associated with future incentive 
compensation. $^{20}$ Whereas the coefficient on $\%$ For Pay Plan with Option Comp tr+1 $_{\text {as }}$ the dependent variable is negative in Panel B of Table III, it is positive and statistically insignificant in Table IV (coefficient of 0.585 and $t$-stat of 0.457 ). The two specifications in which \% For Pay Plan is statistically significant are those with Portfolio Delta $t_{t+1}$ and Comp Mix Con $_{t+1}$ as dependent variables (coefficients of -0.241 and -0.115 , respectively, and $t$-stats of -4.443 and -2.512 , respectively). However, the sign of both coefficients is inconsistent with the prediction that directors respond to lower support for equity pay plans by reducing equity incentives and equitybased pay. $^{21}$

D. Regression discontinuity design (RDD) analyses

Tables V and VI report the results of our RDD analyses. Panels A and B of Table V consider one- and two-year-ahead (i.e., years $t+1$ and $t+2$ ) compensation-related variables, respectively. Table VII considers outcomes related to subsequent actions that firms may take in response to failing to receive sufficient shareholder support for an equity pay plan, such as whether the firm makes an additional request for shares, the number of shares requested by a subsequent proposal, and the number of shares approved by shareholders in a subsequent proposal, in each case in year $t+1$.

The analysis in Table V follows Lee and Lemieux (2010) and uses "excess" versions of the incentive-compensation variables, which are defined as the residuals from the respective

\footnotetext{
${ }^{20}$ The first-stage model is similar to the specification of shareholder support for equity pay plans presented in Table II, except that we also include ISS For Pay Plan as an additional explanatory variable. Because the resulting estimates are similar to those reported in Table II, we do not tabulate the first-stage estimates, but note that ISS For Pay Plan has a strong positive relationship with \% For Pay Plan, which suggests that it is a strong instrument (the Kleibergen and Paap (2006) $F$-statistic is at least 647 in each specification). We address the validity of ISS recommendations as an instrumental variable in more detail below when we discuss the results of our IV analysis of shareholder support in director elections, where we find modest evidence of a positive relation between shareholder support and future CEO incentive compensation in some specifications.

${ }^{21}$ In untabulated analyzes, we find that there are no statistically significant associations between shareholder support and two-year ahead compensation outcomes in this instrumental variables specification.
} 
regressions in Table III. ${ }^{22}$ Finally, because there is no generally accepted method for choosing the appropriate bandwidth over which to estimate the local linear regression (Lee and Lemieux, 2010), we report the results using a bandwidth of 0.02 (which we label 100) and both a shorter and wider bandwidth (i.e., 0.01 and 0.04, which are labeled 50 and 200, respectively). Although certain compensation-related variables are significant in some specifications (e.g., Excess $\log \left(\right.$ Portfolio Delta $\left.t_{t+2}\right)$ in Panel B), the collective evidence from Table V does not indicate a causal effect of failure to receive sufficient shareholder support for an equity pay plan on future CEO incentive-compensation.

The lack of an effect can also be seen in Figure 2, which plots the fitted values of local polynomial regressions on either side of the $50 \%$ discontinuity in the percentage of votes in favor of the pay plan (\% For Pay Plan) for the six one-year-ahead incentive-compensation outcomes (i.e., the dependent variables in Table V, Panel A). In each case, the regression lines essentially meet and show little sign of a discontinuity, which would be visual evidence of a causal effect of failing a shareholder vote. These figures corroborate the lack of statistically signficant differences in Panel A of Table V.

Given that the votes on equity pay plans are binding in the sense that a failed vote deprives firms of the requested equity for compensation purposes, the absence of an effect of a failed shareholder vote on future compensation is surprising. To better understand the actions that firms may take to avoid curtailing, or otherwise altering compensation practices in response to shareholder rejection of equity pay plans, we examine a number of additional outcomes that

\footnotetext{
${ }^{22}$ In principle, additional control variables are not needed for identification in RDD. However, similar to other types of random experiment, the inclusion of relevant controls reduces sampling variability and the precision of the resulting estimate of the treatment effect. In addition, using "excess" measures of the various dependent variables allows for a more accurate visual representation of any effect of shareholder voting on equity pay plans in Figure 2. See Lee and Lemieux (2010) for further discussion of this issue.
} 
reflect actions that firms may take in response to a failed shareholder vote. ${ }^{23}$ Results from this analysis are presented in Table VI. The first variable, Proposal $_{t+1}$, is an indicator that equals one if the firm seeks additional shares in the year following a proposal. It is plausible that failing to garner sufficient shareholder support for an equity pay plan forces a firm to seek shares in a proposal in the following year. Consistent with this prediction, the estimated effect of shareholder rejection of a plan is a 0.42 increase in the probability of seeking shares in the following year (we focus on the Bandwidth 200 results throughout, though results provided in Table VI are similar for narrower bandwidths). This effect is clearly economically consequential and statistically significant ( $t$-stat of -4.44). We also examine the number of shares requested in the following year, with missing values coded as zero (i.e., we treat years in which no shares are sought as requesting zero shares). Consistent with our earlier results, the estimated effect is negative and significant (coefficient of -0.020 and $t$-stat of -3.124 ). Finally, we examine a Shares Approved Apt $_{t+1}$ which measures the number of shares approved by shareholders in years $t$ and $t+1$. However, we find little evidence of a difference in the number of shares approved between firms whose plans were rejected and firms whose plans were approved by shareholders (coefficient of -0.015 and $t$-stat of 1.266). The results in Table VI suggest that the primary consequence of failing to obtain shareholder approval for an equity pay plan is that firms are more likely seek additional shares in the subsequent year and that shareholder generally approve these subsequent requests, which together result in little apparent difference between the compensation practices of firms where shareholders vote down a proposed equity pay plan and their counterparts where shareholders approve the plan.

\footnotetext{
${ }^{23}$ In addition, we examine shareholder support and find little evidence of any difference in shareholder support for plans put to a shareholder vote in year $t+1$. That said, this analysis is clearly problematic, as we do not observe shareholder support in years in which firms do not propose an equity pay plan.
} 
To properly interpret our RDD results, it is crucial to appreciate the causal effect that is being estimated. As discussed in Hahn, Todd, and Van der Klaauw (2001, p.207), one limitation of the RDD approach "is that it only identifies treatment effects locally at the point at which the probability of receiving treatment changes discontinuously." In our setting, the treatment effects we identify weights observations according to their probability of being a close vote. As such, our RDD analysis clearly does not speak to the effect of losing a vote that shareholders would otherwise overwhelmingly support. We do not, however, view this as a major limitation of our analysis. As discussed in Lee (2008) and Lee and Lemieux (2010), it is not always clear that the counterfactuals are well defined for observations far from the discontinuity (i.e., the 50\% shareholder approval threshold). In other words, it is unclear what it means for shareholder support to be shifted from, say, $85 \%$ (which, according to Panel A of Table I, is roughly the average level of shareholder support for the equity pay plans in our sample) to below $50 \%$. Moreover, as noted by Hahn, Todd, and Van der Klaauw (2001, p.207), "in some cases [the] localized parameter is precisely the parameter of interest." In our setting, it is reasonable to view the effect of losing a vote that is weighted according to the probability of losing as the most relevant, since plans with overwhelming shareholder support seem to be of less interest from a policy perspective.

As discussed above (and illustrated in Panel A of Figure 1), there is a clear discontinuity in the distribution of voting outcomes around the 50\% threshold. Listokin (2008) finds similar evidence across a variety of management-sponsored proposals submitted for shareholder vote. Although Listokin $(2008,162)$ suggests that "the mechanism whereby management obtains accurate information and seeks to influence the vote is unclear," Listokin $(2008,162)$ speculates that "management may apply intense campaigning effort to sway votes and/or adjust poll-closing 
times in order to gain victory." McCrary (2008) shows that estimated treatment effects may be biased when there is manipulation of the "running variable" (i.e., the continuous variable that assigns subjects to the treatment or control groups, which is \% For Pay Plan in our research setting). The bias stems, in part, from the likely relation between the unobserved treatment effect and the level of manipulation. In our setting, it is possible that managers of firms that anticipate greater negative consequences of shareholder rejection of their equity compensation proposals are the ones who will exert additional efforts to cross the 50\% threshold in the case of a close vote. However, as discussed by Lee and Lemieux (2010), manipulation of the treatment variable does not invalidate RDD as long as subjects are "unable to precisely manipulate the assignment variable" (emphasis original). The fact that some of our sample firms just fail the vote suggests that management cannot exercise precise control over the voting outcome. Nevertheless, if there is a differential in the degree to which management can exercise control of the vote, our estimate of the treatment effect will be downwardly biased, and our failure to find an effect may be attributable to managements' differential ability to manipulate the vote.

Notwithstanding the possible bias in our estimated potential effect of shareholder rejection of equity compensation plans, we do not find evidence of an actual effect of such rejection. Our results are instead consistent with two types of firms that comprise our sample. The first type faces no material effect in terms of future compensation from shareholder rejection of their equity compensation plan and so has less incentive to manipulate the vote. The second type faces a potential effect on future compensation, but management is able to push the vote across the threshold and avoid such effects. Even if correct, this explanation for the absence of significant estimated effects provides little assurance regarding the efficacy of the requirement to submit equity compensation plans to shareholder vote because it suggests that management can 
manipulate votes that are in danger of failing.

\section{E. Shareholder support in director elections and future compensation}

Given that our findings are generally inconsistent with those of prior studies that examine the relation between shareholder support for directors and future compensation (e.g., Cai et al., 2009; Fischer et al., 2009), we repeat our cross-sectional and instrumental variables analyses on a larger sample of director elections than was examined in prior studies. ${ }^{24}$ To construct our sample of director elections, we select all director elections on ISS Voting Analytics for which a director name is provided. This yields 120,554 votes related to 50,912 directors at 4,663 firms. We then match these observations with data on directors' committee memberships from Equilar using firm identifiers such as CUSIPs and a "fuzzy match" on director names within each firmyear. This yields data on 104,684 director elections from 2003 through 2010. Combining these with data on CEO compensation (described above) reduces our sample to 102,534 observations from 4,043 distinct firms (18,598 firm-years).

Panel A of Table VII presents estimates from cross-sectional regressions of one-yearahead incentive-compensation variables for our sample of director elections regardless of whether there is a vote on an equity pay plan at the annual meeting. We find little evidence that future CEO compensation is affected by the level shareholder support for directors. However, in the second-to-last column we find that the total number of options granted to all of the firm's employees in the year following the director election (Options Granted $_{t+1}$ ) is significantly negatively related to shareholder support for directors (coefficient $-0.004, t$-stat -4.35 ), which stands in contrast to the conventional prediction of a positive coefficient. However, somewhat

\footnotetext{
${ }^{24}$ Note that because it is extremely rare for directors to fail to receive less than $50 \%$ of shareholder support (as illustrated in Panel B of Figure 1). Thus, it is not feasible to conduct a RDD analysis with respect to this type of vote.
} 
consistent with prior research, we find that future CEO turnover is less likely when there is greater support for directors (coefficient on \% For Director for CEO Turnover $_{t+1}$ of $-0.015, t$-stat $-3.25)$.

Following prior research, we also conducted analyses similar to those in Table VII, but with subsamples restricted to (i) elections of only those directors who chair the firm's compensation committee, and (ii) all directors on the firm's compensation committee. This analysis is motivated by the idea that these directors may be more responsive to shareholder votes than other directors regarding executive compensation decisions. In each case (untabulated), we find no statistically significant association between any of the dependent

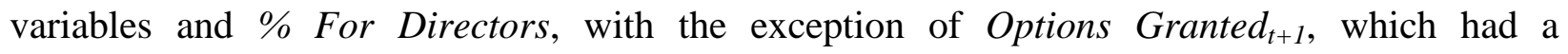
statistically significant negative coefficient in both subsamples.

Similar to our analysis of votes on equity pay plans, we also estimate instrumental variable regressions of various one-year-ahead (i.e., year $t+1$ ) incentive-compensation variables on shareholder voting support for a director up for election (\% For Director) using ISS's voting recommendation (ISS For Director) as the instrument for shareholder support. Results from this analysis are presented in Panel B of Table VII. In contrast to the OLS results in Panel A, we find a positive relation between shareholder support for directors and the value of future stock grants to CEOs (coefficient on \% For Director for Option Comp t $_{t+1}$ of 2.32, t-stat. of 2.19) and total future CEO compensation (coefficient on $\%$ For Director for Total Comp $t_{t+1}$ of 0.24 , $t$-stat. of 2.59). Consistent with the effect on future stock grants, we also find evidence of positive relations between shareholder support for directors and CEOs' equity portfolio delta (coefficient on \% For Director for Portfolio Delta $t_{t+1}$ of $0.35, t$-stat. of 1.74), and compensation mix (coefficient on \% For Director for Comp Mix $x_{t+1}$ of 0.096, $t$-stat. of 2.85). Moreover, the negative 
associations between shareholder support for directors and future aggregate option grants and future CEO turnover observed in Panel A are not evident in the III analysis in Panel B.

Although the IV results in Panel B of Table VII are consistent with prior studies, it is possible that our instrument is not perfectly exogenous with respect to future incentivecompensation outcomes. Because of this concern, we examine the sensitivity of our IV analysis to relaxing the assumption that ISS For Director is not strictly exogenous. In particular, we follow the partial identification approach outlined by Ashley (2009) to examine the sensitivity of the estimated coefficients to a positive relationship between the unobserved error and ISS For Director, which reflects the concern that firms may directly reduce compensation in response to an unfavorable ISS recommendation (rather than only indirectly through the effect of ISS's recommendation on shareholder support). For brevity, we only discuss the sensitivity of the results for Option Comp t+1 $_{1}$ and Total Comp Col $_{t+1}$ In our sensitivity analysis, we find that an assumed correlation between the instrument and the unobserved error term as small as 0.022 (0.020) is sufficient to cause the estimated coefficient on \% For Director to be negative when Option Comp Cot+1 $_{\text {Tol Comp }}$ (T) is the dependent variable. For comparison, using the approach of Ashley (2009), the estimated correlation between \% For Director and the unobserved error term when ISS For Director is assumed to be perfectly exogenous has a magnitude of 0.041 (0.037). These magnitudes indicate that even if ISS For Director is much less correlated with the error than $\%$ For Director is, the estimated effect on \% For Director will be zero or negative, which would produce inferences that are inconsistent with those of prior studies. ${ }^{25}$ Therefore, although

\footnotetext{
${ }^{25}$ Another way of characterizing the highly sensitive relationship between $\%$ For Directors and future incentivecompensation measures in our instrumental variables analysis is that, even though ISS For Director is a strong instrument (i.e., it produces substantial variation in \% For Director), the strength of the statistical relationship (as well as the economic magnitude) between $\%$ For Director and the various future incentive-compensation variables is modest.
} 
our results provide some evidence that shareholder support for director elections has the effect predicted in prior research, our sensitivity analysis suggests that these results are highly sensitive to even a small correlation between ISS For Director and the error term in the regression. ${ }^{26}$

The results in Table VII provide little evidence that directors respond to lower shareholder support by reducing future CEO compensation or aggregate option grants to the firms' employees. Overall, our findings are inconsistent with inferences from other studies (e.g., Cai et al., 2009; Fischer et al., 2009). However, these results are broadly consistent with our findings in Table III that consider the subset of director elections when there is also a vote on an equity compensation plan.

\section{Conclusion}

This study examines the effects of shareholder support for equity compensation plans on the level and composition of future CEO incentive compensation and future aggregate (i.e., firmwide) stock option grants. We find virtually no statistical evidence that either lower shareholder support for, or the outright rejection of, proposed equity compensation plans leads to decreases in future CEO incentive-compensation or firm-wide stock option grants. This null result obtains even after applying instrumental variable and regression discontinuity approaches to mitigate concerns about the endogenous nature of shareholder voting. The lack of an effect of shareholder rejection of equity compensation plans is surprising. As we demonstrate, shareholder support for these plans does have the predicted negative relation with the level and composition of "excess" executive compensation reported to shareholders in advance of the vote, suggesting that these are matters of concern to shareholders when deciding how to vote. Furthermore, the voting outcomes

\footnotetext{
${ }^{26}$ We reach a similar conclusion in our sensitivity analysis of Portfolio Delta $a_{t+1}$ and Comp Mix $x_{t+1}$, the other two variables with statistically significant associations with \% For Director.
} 
are binding and their natural effects are relatively easy to identify and measure ex post (e.g., it is reasonable to expect that a shareholder rejection of a request for additional shares for a stock option plan should lead to fewer stock option grants in the future). Collectively, our results raise doubts about the efficacy of shareholder voting as a corporate governance mechanism for influencing executive compensation, and also call into question the efficacy of recent regulatory efforts that have focused on strengthening shareholder voting rights, particularly with regard to executive compensation. 


\section{References}

Ashley, R. (2009). Assessing the credibility of instrumental variables inference with imperfect instruments via sensitivity analysis. Journal of Applied Econometrics 24, 325-337.

Burns, N., S. Kedia. (2006). The impact of performance-based compensation on misreporting. Journal of Financial Economics 79, 35-67.

Bushee, B., Carter, M., and Gerakos, J. (2010). Institutional investor preferences for corporate governance mechanisms. Working paper, University of Pennsylvania.

Cai, J. and Walkling, R. (2009). Shareholders' say on pay: Does it create value? Journal of Financial and Quantitative Analysis, Forthcoming

Cai, J., Garner, J., and Walkling, R. (2009). Electing directors. The Journal of Finance 64 (5): 2389-2421.

Carter, M. and Zamora, V. (2009). Shareholder remuneration votes and CEO compensation design. Working paper, Boston College.

Choi, S.J., Fisch, J.E., and Kahan, M. (2011). Voting through agents: How mutual funds vote on director elections. Working paper, University of Pennsylvania.

Coles, J.L., Daniel, N.D., and Naveen, L. (2006). Managerial incentives and risk-taking. Journal of Financial Economics 79, 431-468.

Core, J.E. and Guay, W.R. (1999). The use of equity grants to manage optimal equity incentive levels. Journal of Accounting and Economics 28, 151-184.

Core, J.E. and Guay, W. R. (2002). Estimating the value of employee stock option portfolios and their sensitivities to price and volatility. Journal of Accounting Research 40: 613-630.

Core, J.E., Guay, W.R., and Larcker, D.F. (2008). The power of the pen and executive compensation. Journal of Financial Economics 88, 1-25.

Core, J.E., Holthausen, R.W., Larcker, D.F. (1999). Corporate governance, chief executive officer compensation, and firm performance. Journal of Financial Economics 51, 371-406.

Cuñat, V., Gine, M., and Guadalupe, M. (2012). The vote is cast: the effect of corporate governance on shareholder value. Journal of Finance, Forthcoming.

Del Guercio, D., Seery, L., and Woidtke, T. (2008). Do boards pay attention when institutional investor activists “just vote no"? Journal of Financial Economics 90: 84-103.

Engel, E., Hayes, R.M., Wang, X. (2003). CEO turnover and properties of accounting information. Journal of Accounting and Economics 36: 197-226.

Ertimur, Y., Ferri, F., and Muslu, V. (2010). Shareholder activism and CEO pay. Review of Financial Studies 24(2): 535-592.

Ferri, F., and Maber, D.A. (2011). Say on pay votes and CEO compensation: Evidence from the UK. Working paper, Columbia Business School.

Fischer, P., Gramlich, J., Miller, B., and White, H. (2009). Investor perceptions of board performance: Evidence from uncontested director elections. Journal of Accounting and Economics 48: 172-189. 
Gompers, P., Ishii, J., and Metrick, A. (2003). Corporate governance and equity prices. Quarterly Journal of Economics 118 (1): 107-155

Hahn, J., Todd, P., and Van der Klaauw, W. (2001). Identification and estimation of treatment effects with a regression-discontinuity design. Econometrica 69 (1): 201-209.

Kleibergen, F. and Paap, R. 2006. Generalized reduced rank tests using the singular value decomposition. Journal of Econometrics 133: 97-126.

Larcker, D.F., Ormazabal, G., Taylor, D. (2011). The market reaction to corporate governance regulation. Journal of Financial Economics, Forthcoming.

Lee, D. (2008). Randomized experiments from non-random selection in U.S. House elections. Journal of Econometrics 142 (2): 675-697.

Lee, D., and Lemieux, T. (2010). Regression discontinuity designs in economics. Journal of Economic Literature 48: 281-355.

Listokin, Y. (2009). Corporate voting versus market price setting. American Law and Economics Review 11 (2): 608-635.

Listokin, Y. (2008). Management always wins the close ones. American Law and Economics Review 10 (2): 159-184.

Martin, K., and Thomas, R. (2005). When is enough, enough? Market reaction to highly dilutive stock option plans and the subsequent impact on CEO compensation. Journal of Corporate Finance 11: 61-83.

McCrary, J. (2008). Manipulation of the running variable in the regression discontinuity design: A density test. Journal of Econometrics 142: 698-714

Morgan, A., Poulsen, A., and Wolf, J. (2006). The evolution of shareholder voting for executive compensation schemes. Journal of Corporate Finance .

Morgan, A., Poulsen, A., Wolf, J., and Yang, T. (2010). Mutual funds as monitors: Evidence from mutual fund voting. Working paper, Clemson University.

Morgan, S. L. and Winship, C. (2007). Counterfactuals and Causal Inference: Methods and Principles for Social Research. Cambridge University Press, Cambridge, UK.

Pearl, J. (2000). Causality: Models, Reasoning, and Inference. Cambridge University Press, Cambridge, UK.

Yermack, D. (2010). Shareholder voting and corporate governance. Annual Review of Financial Economics 2: 2.1-2.23. 


\section{Figure 1 \\ Histogram of Voting Percentages \\ Panel A: Equity Compensation Plans}

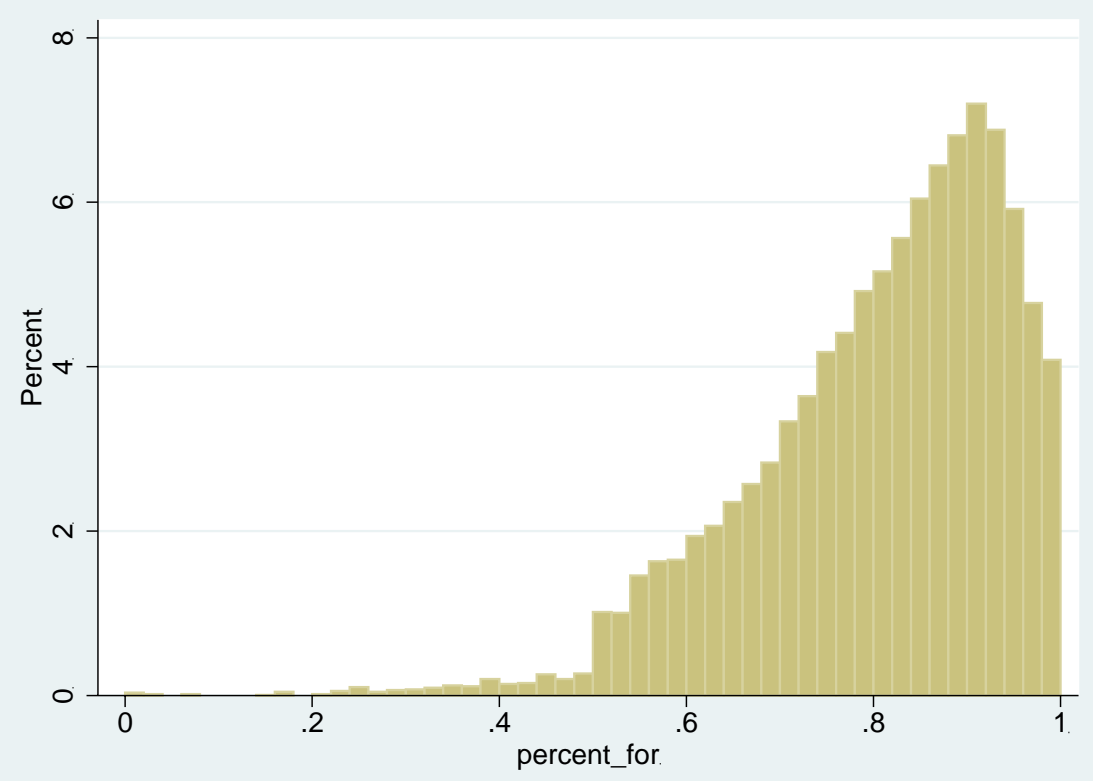

This figure presents a histogram of the percentage of votes in favor of management-sponsored equity compensation plans ( $\%$ For Pay Plan).

\section{Panel B: Director Elections}

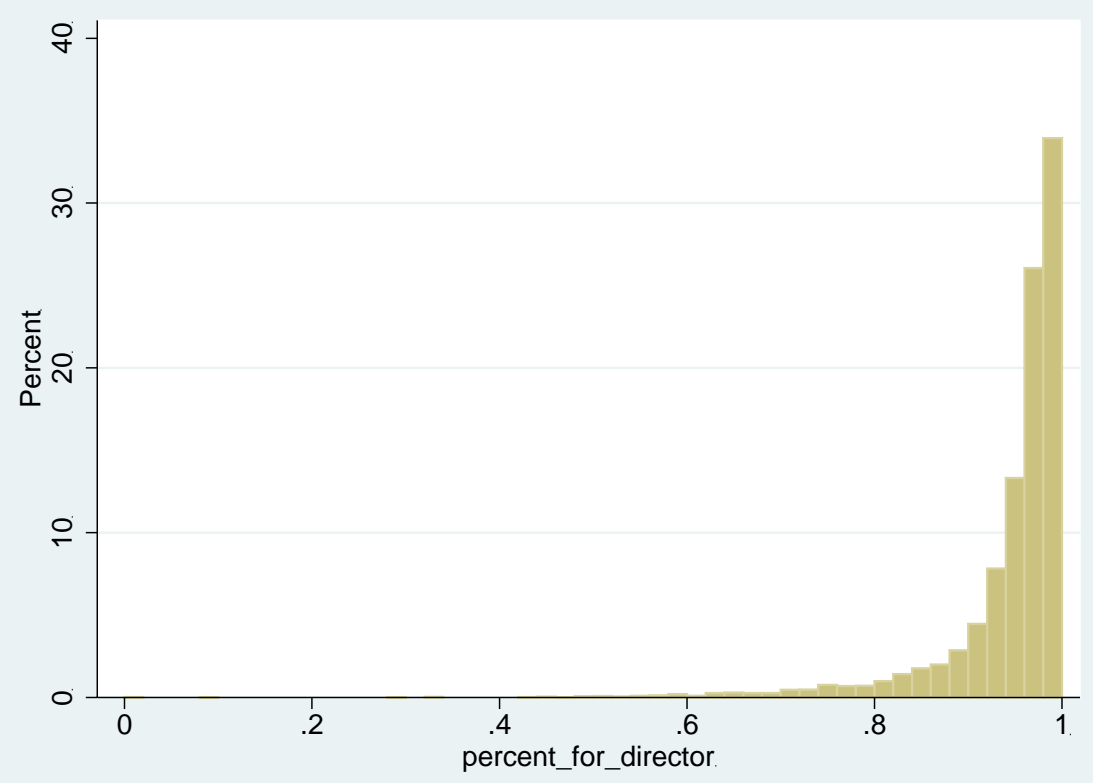

This figure presents a histogram of the percentage of votes in favor of directors (\% For Directors). 


\section{Figure 2}

\section{Regression Discontinuity Plots of Excess Contemporaneous Compensation Variables}

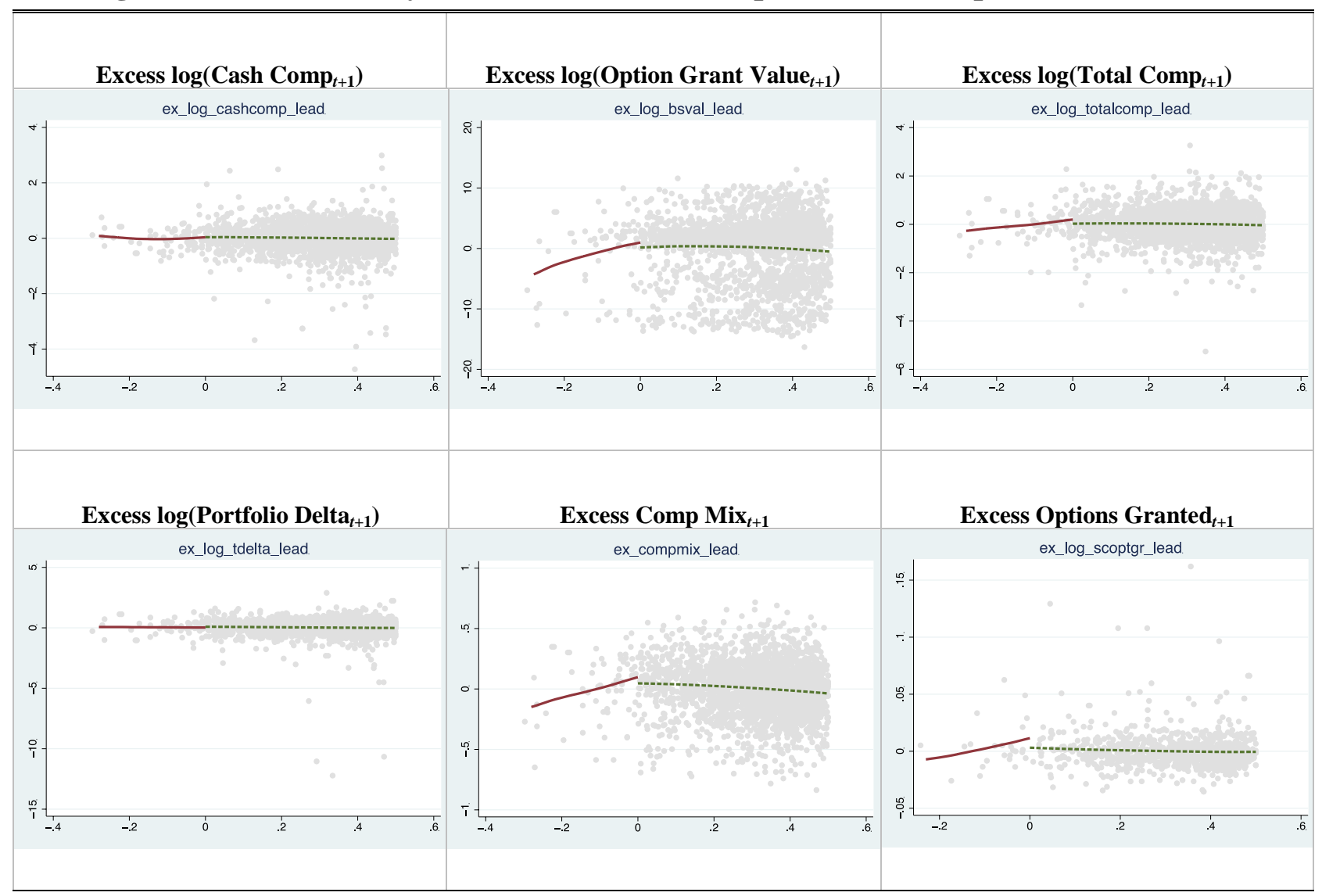

These figures present plots of the fitted values of local polynomial regressions on either side of the $50 \%$ discontinuity in the percentage of votes in favor of the pay plan (\% For Pay Plan). The dependent variables are excess one year-ahead (i.e., for the fiscal year following the year of the shareholder meeting) compensation variables defined as the residuals from the regressions in Table IV, Panel B. The bandwidth is 0.04 ("Bandwidth 200") and a triangular kernel is used for the estimation. 


\section{Table I}

\section{Descriptive Statistics}

\section{Panel A: By Vote Outcome}

\begin{tabular}{|c|c|c|c|c|c|c|c|}
\hline & $\begin{array}{c}\text { All } \\
\text { Votes }\end{array}$ & $\begin{array}{c}\text { All Passing } \\
\text { Votes }\end{array}$ & $\begin{array}{c}\text { All Failing } \\
\text { Votes }\end{array}$ & $\begin{array}{c}\text { All Close } \\
\text { Votes }\end{array}$ & $\begin{array}{l}\text { Close } \\
\text { Passes }\end{array}$ & $\begin{array}{l}\text { Close } \\
\text { Fails }\end{array}$ & $\begin{array}{l}\text { Difference } \\
\text { in Medians }\end{array}$ \\
\hline$\%$ For Pay Plan & $83.3 \%$ & $83.7 \%$ & $41.0 \%$ & $52.1 \%$ & $52.7 \%$ & $47.5 \%$ & $12.302 * * *$ \\
\hline$\%$ For Directors & $96.9 \%$ & $97.0 \%$ & $92.9 \%$ & $95.1 \%$ & $95.3 \%$ & $92.8 \%$ & $2.098 * *$ \\
\hline CEO Tenure $_{t-1}$ & 5.00 & 5.00 & 6.15 & 6.45 & 6.30 & 7.70 & -1.000 \\
\hline Revenue $_{t-1}$ & 564 & 586 & 158 & 253 & 260 & 224 & $1.762 *$ \\
\hline Book-to-market $_{t-1}$ & 0.429 & 0.430 & 0.417 & 0.412 & 0.404 & 0.443 & -0.983 \\
\hline$R O A_{t}$ & 0.033 & 0.033 & 0.027 & 0.026 & 0.026 & 0.023 & 0.555 \\
\hline$R O A_{t-1}$ & 0.034 & 0.034 & 0.020 & 0.027 & 0.023 & 0.032 & -0.697 \\
\hline$R O A_{t-2}$ & 0.036 & 0.036 & 0.028 & 0.030 & 0.033 & 0.028 & 1.320 \\
\hline Stock Return $_{t}$ & 0.114 & 0.112 & 0.183 & 0.155 & 0.189 & 0.111 & 0.651 \\
\hline Stock Return $_{t-1}$ & 0.074 & 0.073 & 0.098 & 0.114 & 0.133 & 0.054 & 1.197 \\
\hline Stock Return $_{t-2}$ & 0.118 & 0.118 & 0.106 & 0.158 & 0.176 & 0.091 & 1.501 \\
\hline 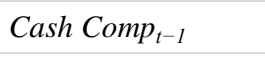 & 735,152 & 742,899 & 579,685 & 588,750 & 612,491 & 484,516 & $2.087 * *$ \\
\hline Option Value $_{t-1}$ & 525,161 & 521,459 & 649,226 & 519,122 & 513,141 & 542,208 & 0.119 \\
\hline Total Comp $_{t-1}$ & $2,265,832$ & $2,270,042$ & $2,010,153$ & $1,830,345$ & $1,845,581$ & $1,752,685$ & $1.678 *$ \\
\hline Portfolio Delta $_{t-1}$ & 246,484 & 248,591 & 195,741 & 194,517 & 184,794 & 224,865 & 0.708 \\
\hline Comp Mix $x_{t-1}$ & 0.522 & 0.522 & 0.536 & 0.547 & 0.566 & 0.532 & 1.012 \\
\hline${\text { Options } \text { Granted }_{t-1}}_{1}$ & 0.012 & 0.012 & 0.026 & 0.020 & 0.020 & 0.022 & -0.645 \\
\hline
\end{tabular}

This table presents the median of the primary variables according to voting outcome as defined in the caption of Panel B. The column labeled Difference in Medians presents the z-statistic for a two-sample Wilcoxon rank-sum test of difference in medians between Close Passes and Close Fails. ***, **, and * denote statistical significance (two-sided) at the 1\%, 5\%, and 10\% levels, respectively. \% For Pay Plan is the percentage of shareholder votes in favor of the pay plan. \% For Directors is the number of votes for a director divided by the sum of votes for that director and the votes withheld. CEO Tenure $t_{-1}$ is number of years the current CEO has held the CEO title as of the end of the fiscal year prior to the shareholder vote. Revenue $t_{t-1}$ is total revenue in the

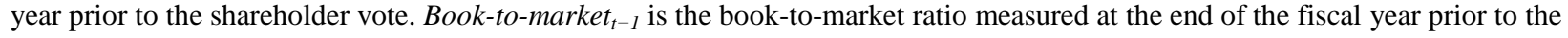
shareholder vote. $R O A_{t}, R O A_{t-1}, R O A_{t-2}$ are return on assets, measured as income before interest and taxes scaled by average total assets during the year of, the year prior to, and two years prior to the year of the shareholder vote, respectively. Stock Return $_{t}$, Stock Return $t_{-1}$, Stock Return $t_{-2}$ are the annual stock returns during the year of, the year prior to, and the two years prior to the year of the shareholder vote, respectively. Cash Comp $t_{-1}$ is the CEO's annual cash compensation (salary plus bonus) during the year prior to the shareholder vote. Option Value $t_{-1}$ is the Black-Scholes value the CEO's option grants during the year prior to the shareholder vote. Total Comp Col $_{-1}$ is the total annual compensation of the CEO during the year prior to the shareholder vote. Portfolio Delta $t_{-1}$ is the change in the risk-neutral value of the CEO's equity portfolio for a $1 \%$ change in stock price as of the end of the fiscal year prior to the shareholder vote. Comp $M_{i t_{t-1}}$ is one minus salary scaled by total annual compensation of the CEO during the fiscal year prior to the shareholder vote. Options Granted $_{t-1}$ is the aggregate number of options granted scaled by the total number of shares outstanding during the fiscal year prior to the shareholder vote. 


\section{Table I (cont'd)}

Panel B: Number of Votes by Year and Outcome

\begin{tabular}{|c|c|c|c|c|c|c|c|}
\hline \hline Year & $\begin{array}{c}\text { All } \\
\text { Votes }\end{array}$ & $\begin{array}{c}\text { All Passing } \\
\text { Votes }\end{array}$ & $\begin{array}{c}\text { All Failing } \\
\text { Votes }\end{array}$ & $\begin{array}{c}\text { All Close } \\
\text { Votes }\end{array}$ & $\begin{array}{c}\text { Close } \\
\text { Passes }\end{array}$ & $\begin{array}{c}\text { Close } \\
\text { Fails }\end{array}$ \\
\hline 2000 & 874 & 860 & 14 & 29 & 23 & 6 \\
\hline 2001 & 1,037 & 1,018 & 19 & 37 & 30 & 7 \\
\hline 2002 & 1,025 & 1,003 & 22 & 43 & 36 & 7 \\
\hline 2003 & 1,072 & 1,037 & 35 & 46 & 36 & 10 \\
\hline 2004 & 1,102 & 1,067 & 35 & 63 & 52 & 11 \\
\hline 2005 & 925 & 906 & 19 & 33 & 26 & 7 \\
\hline 2006 & 768 & 751 & 17 & & 38 & 30 & 8 \\
\hline 2007 & 886 & 864 & 22 & & 35 & 26 & 9 \\
\hline 2008 & 986 & 967 & 19 & & 32 & 28 & 4 \\
\hline 2009 & 845 & 835 & 10 & & 22 & 20 & 2 \\
\hline Total & 9,520 & 9,308 & 212 & 378 & 307 & 71 \\
\hline
\end{tabular}

This table presents the number of votes on equity compensation plans during each fiscal year in our sample according to outcome. All Votes is the total number of shareholder votes. All Passing Votes is the total number of shareholder votes that received more than $50 \%$ of the shareholder votes. All Failing Votes is the total number of shareholder votes that received less than $50 \%$ of the shareholder votes. All Close Votes is the total number of shareholder votes that received between $45 \%$ and $55 \%$ of the shareholder votes. Close Passes is the total number of shareholder votes that received between $50 \%$ and $55 \%$ of the shareholder votes. Close Fails is the total number of shareholder votes that received between $45 \%$ and $50 \%$ of the shareholder votes.

\begin{tabular}{|c|c|c|c|}
\multicolumn{3}{|c|}{ Panel C: Frequency of Voting During Sample Period } \\
\hline \hline $\begin{array}{c}\text { Number of } \\
\text { Vote Years }\end{array}$ & Frequency & Percent & $\begin{array}{c}\text { Cumulative } \\
\text { Percent }\end{array}$ \\
\hline 0 & 1,002 & $21.05 \%$ & $21.05 \%$ \\
\hline 1 & 1,400 & $29.42 \%$ & $50.47 \%$ \\
\hline 2 & 961 & $20.19 \%$ & $70.67 \%$ \\
\hline 3 & 677 & $14.23 \%$ & $84.89 \%$ \\
\hline 4 & 398 & $8.36 \%$ & $93.25 \%$ \\
\hline 5 & 169 & $3.55 \%$ & $96.81 \%$ \\
\hline 6 & 80 & $1.68 \%$ & $98.49 \%$ \\
\hline 7 & 44 & $0.92 \%$ & $99.41 \%$ \\
\hline 8 & 11 & $0.23 \%$ & $99.64 \%$ \\
\hline 9 & 15 & $0.32 \%$ & $99.96 \%$ \\
\hline 10 & 2 & $0.04 \%$ & $100.00 \%$ \\
\hline Total & 4,759 & $100.00 \%$ & \\
\hline
\end{tabular}

This table presents the frequency with which the 4,759 unique firms (and 24,784 firm-years) in our ISS Voting Analytics sample vote on an equity compensation plan during our sample period from 2001 and 2010. The first and second columns report the number of times the firm has a vote on an equity compensation plan and the number of firms with that number of votes, respectively. The third and fourth columns report the percent of the sample and the cumulative percent having a given number of votes during the sample period, respectively. 
Table II

Shareholder Voting

\begin{tabular}{|c|c|c|c|c|}
\hline & $\begin{array}{c}\% \text { For } \\
\text { Directors }\end{array}$ & $\begin{array}{c}\% \text { For } \\
\text { Directors }\end{array}$ & $\begin{array}{c}\% \text { For } \\
\text { Pay Plan }\end{array}$ & $\begin{array}{c}\% \text { For } \\
\text { Pay Plan }\end{array}$ \\
\hline \multirow[t]{2}{*}{$\%$ For Directors } & & & $0.327 * * *$ & \\
\hline & & & $(6.719)$ & \\
\hline \multirow{2}{*}{$\%$ For Pay Plan } & $0.113 * * *$ & & & \\
\hline & (5.719) & & & \\
\hline \multirow[t]{2}{*}{ Shares Requested } & $0.048^{*}$ & -0.030 & $-0.679 * * *$ & $-0.561 * * *$ \\
\hline & (1.866) & $(-1.297)$ & $(-5.782)$ & $(-15.450)$ \\
\hline \multirow[t]{2}{*}{ Shares Available } & 0.058 & 0.017 & $-0.372 * * *$ & $-0.367 * * *$ \\
\hline & $(1.323)$ & $(0.416)$ & $(-4.845)$ & $(-5.078)$ \\
\hline \multirow[t]{2}{*}{ Comp $\operatorname{Mix}_{t-1}$} & $0.001 * * *$ & 0.000 & $-0.003 * * *$ & $-0.002 * * *$ \\
\hline & $(3.136)$ & (1.453) & $(-5.689)$ & $(-6.623)$ \\
\hline \multirow[t]{2}{*}{$\log \left(\right.$ Total $\left.\operatorname{Comp}_{t-1}\right)$} & 0.003 & 0.002 & $-0.008 * *$ & $-0.006^{* *}$ \\
\hline & (1.017) & $(0.685)$ & $(-2.007)$ & $(-2.158)$ \\
\hline \multirow[t]{2}{*}{$\log \left(\right.$ CEO Tenure $\left._{t-1}\right)$} & $0.004 * * *$ & $0.004 * * *$ & 0.003 & 0.003 \\
\hline & (3.266) & $(4.220)$ & $(1.081)$ & $(1.299)$ \\
\hline \multirow[t]{2}{*}{$\log \left(\right.$ Revenue $\left._{t-1}\right)$} & $-0.026 * * *$ & $-0.029 * * *$ & -0.012 & $-0.008^{*}$ \\
\hline & $(-5.370)$ & $(-6.030)$ & $(-1.418)$ & $(-1.659)$ \\
\hline \multirow[t]{2}{*}{ Book-to-market $t_{\text {-1 }}$} & 0.024 & $0.026^{* *}$ & 0.009 & $-0.035 * *$ \\
\hline & $(1.625)$ & $(1.985)$ & $(0.299)$ & $(-2.308)$ \\
\hline \multirow[t]{2}{*}{$R O A_{t-1}$} & $-0.034 * * *$ & $-0.030 * * *$ & 0.038 & 0.020 \\
\hline & $(-5.107)$ & $(-5.643)$ & $(1.218)$ & $(0.675)$ \\
\hline \multirow[t]{2}{*}{$R O A_{t-2}$} & $-0.004 * * *$ & $-0.005^{* * *}$ & -0.007 & -0.001 \\
\hline & $(-3.495)$ & $(-5.811)$ & $(-1.242)$ & $(-0.127)$ \\
\hline \multirow[t]{2}{*}{ Stock Return $_{t-1}$} & $0.005^{* *}$ & $0.004 * *$ & -0.002 & 0.001 \\
\hline & $(2.314)$ & $(2.033)$ & $(-0.619)$ & $(0.352)$ \\
\hline \multirow[t]{2}{*}{ Stock Return $_{t-2}$} & $0.794 * * *$ & $0.895^{* * *}$ & $0.604 * * *$ & $0.857 * * *$ \\
\hline & $(48.000)$ & $(153.117)$ & (16.097) & (78.391) \\
\hline Observations & 2,221 & 2,221 & 2,221 & 3,070 \\
\hline R-squared & 0.127 & 0.094 & 0.174 & 0.110 \\
\hline
\end{tabular}

This table presents the results of estimating regressions of either the percentage of votes cast in favor a director (\% For Directors) or the percentage of votes cast in favor of the pay plan (\% For Pay Plan). Shares Requested is the number of shares requested by the pay plan scaled by the number of shares outstanding. Shares Available is the number of stock options and restricted stock that have not yet been granted scaled by the number of shares outstanding. All of the remaining variables are as defined in the caption of Table I. Industry (two-digit SIC) and year indicators are included but unreported. ***, **, and * denote statistical significance (two-sided) at the $1 \%, 5 \%$, and $10 \%$ levels, respectively. Standard errors are calculated based on two-way clustering by firm and year. 


\section{Table III}

\section{Effect of Shareholder Voting: Equity-based Compensation Plans}

Panel A: Contemporaneous Compensation Variables

\begin{tabular}{|c|c|c|c|c|c|c|}
\hline & $\begin{array}{l}\text { Cash } \\
\text { Comp }_{t}\end{array}$ & $\begin{array}{l}\text { Option } \\
\text { Comp }_{t}\end{array}$ & $\begin{array}{l}\text { Total } \\
\text { Comp }_{t}\end{array}$ & $\begin{array}{c}\text { Portfolio } \\
\text { Delta }_{t}\end{array}$ & $\begin{array}{l}\text { Comp } \\
\text { Mix }_{t}\end{array}$ & $\begin{array}{c}\text { Options } \\
\text { Granted }\end{array}$ \\
\hline \multirow[t]{2}{*}{ \% For Pay Plan } & -0.053 & $-2.523 * * *$ & $-0.260^{*}$ & -0.130 & $-0.169 * * *$ & $-0.013 * * *$ \\
\hline & $(-1.036)$ & $(-4.279)$ & $(-1.651)$ & $(-1.475)$ & $(-3.066)$ & $(-7.640)$ \\
\hline \multirow[t]{2}{*}{$\%$ For Directors } & -0.070 & $-1.511^{*}$ & 0.015 & -0.093 & 0.006 & 0.000 \\
\hline & $(-0.972)$ & $(-1.829)$ & $(0.120)$ & $(-0.992)$ & $(0.195)$ & $(0.002)$ \\
\hline \multirow[t]{2}{*}{$\log \left(\right.$ CEO Tenure $\left._{t}\right)$} & -0.002 & $-0.379 * * *$ & 0.005 & $-0.045^{* *}$ & $-0.017 * *$ & -0.000 \\
\hline & $(-0.142)$ & $(-4.048)$ & $(0.424)$ & $(-2.540)$ & $(-2.364)$ & $(-0.307)$ \\
\hline \multirow[t]{2}{*}{$\log _{\left(\text {Revenue }_{t}\right)}$} & $0.049 * * *$ & $0.300 * * *$ & $0.145^{* * *}$ & $0.041 * * *$ & $0.019 * * *$ & $-0.001 * * *$ \\
\hline & (2.948) & $(2.974)$ & (5.793) & $(5.292)$ & $(5.438)$ & $(-3.628)$ \\
\hline \multirow[t]{2}{*}{ Book-to-market ${ }_{t}$} & $-0.038 * *$ & -0.568 & $-0.106^{* * *}$ & $-0.091 * * *$ & -0.014 & 0.000 \\
\hline & $(-1.970)$ & $(-1.508)$ & $(-3.108)$ & $(-3.242)$ & $(-0.825)$ & $(0.203)$ \\
\hline \multirow[t]{2}{*}{$R O A_{t}$} & -0.111 & -1.360 & -0.204 & 0.137 & -0.056 & -0.001 \\
\hline & $(-0.967)$ & $(-1.380)$ & $(-1.014)$ & (1.449) & $(-1.305)$ & $(-0.429)$ \\
\hline \multirow[t]{2}{*}{$R O A_{t-1}$} & 0.069 & 0.910 & -0.046 & 0.069 & 0.024 & 0.002 \\
\hline & $(0.339)$ & $(0.995)$ & $(-0.400)$ & $(0.389)$ & $(1.152)$ & $(0.223)$ \\
\hline \multirow[t]{2}{*}{$R O A_{t-2}$} & 0.005 & -0.681 & -0.040 & -0.020 & -0.031 & -0.001 \\
\hline & $(0.036)$ & $(-0.990)$ & $(-0.265)$ & $(-0.358)$ & $(-0.544)$ & $(-0.122)$ \\
\hline \multirow[t]{2}{*}{ Stock Return $_{t}$} & $0.104 * *$ & -0.532 & $0.084 * * *$ & $0.683^{* * *}$ & $-0.038 * * *$ & -0.001 \\
\hline & $(2.526)$ & $(-1.408)$ & $(3.354)$ & $(6.891)$ & $(-4.581)$ & $(-0.945)$ \\
\hline \multirow[t]{2}{*}{ Stock Return R-I $_{1}$} & -0.001 & 0.117 & $0.112 * *$ & $-0.060 * * *$ & 0.024 & -0.001 \\
\hline & $(-0.025)$ & $(0.526)$ & $(2.518)$ & $(-3.229)$ & $(1.422)$ & $(-1.420)$ \\
\hline \multirow[t]{2}{*}{ Stock Return $_{t-2}$} & -0.001 & -0.120 & -0.017 & -0.059 & -0.002 & -0.001 \\
\hline & $(-0.148)$ & $(-1.483)$ & $(-0.578)$ & $(-1.618)$ & $(-0.447)$ & $(-0.615)$ \\
\hline \multirow[t]{2}{*}{ Dep. Var ${ }_{\cdot t-1}$} & $0.743 * * *$ & $0.457 * * *$ & $0.633 * * *$ & $0.942 * * *$ & $0.426 * * *$ & $0.446 * * *$ \\
\hline & $(20.542)$ & (6.069) & (13.032) & $(70.425)$ & $(8.660)$ & (10.539) \\
\hline Observations & 3,528 & 3,528 & 3,528 & 3,211 & 3,523 & 2,074 \\
\hline R-squared & 0.728 & 0.467 & 0.702 & 0.899 & 0.404 & 0.391 \\
\hline
\end{tabular}

This table presents regressions of the contemporaneous (i.e., for the fiscal year that includes the shareholder meeting) incentive compensation variables on pay plan (\% For Pay Plan) and director (\% For Directors) voting outcomes and determinants of incentive compensation. Dep. $\operatorname{Var}_{t-1}$ is the lagged value of the respective dependent variable for the fiscal year prior to the shareholder vote. The remaining variables are as defined in the caption to Panel A of Table I. Industry (two-digit SIC) and year indicators are included but unreported. $* * *, * *$, and * denote statistical significance (two-sided) at the $1 \%, 5 \%$, and $10 \%$ levels, respectively. Standard errors are calculated based on two-way clustering by firm and year. 


\section{Table III (cont'd)}

\section{Panel B: One Year-Ahead Compensation Variables}

\begin{tabular}{|c|c|c|c|c|c|c|c|}
\hline & $\begin{array}{c}\text { Cash } \\
\text { Comp }_{t+1}\end{array}$ & $\begin{array}{l}\text { Option } \\
\text { Comp }_{t+1}\end{array}$ & $\begin{array}{c}\text { Total } \\
\text { Comp }_{t+1}\end{array}$ & $\begin{array}{l}\text { Portfolio } \\
\text { Delta }_{t+1}\end{array}$ & $\begin{array}{l}\text { Comp } \\
\text { Mix }_{t+1}\end{array}$ & $\begin{array}{c}\text { Options } \\
\text { Granted }_{t+1}\end{array}$ & $\begin{array}{c}\text { CEO } \\
\text { Turnover }_{t+1}\end{array}$ \\
\hline \multirow[t]{2}{*}{ \% For Pay Plan } & -0.065 & $-1.213^{* *}$ & -0.096 & -0.165 & $-0.151 * * *$ & -0.005 & -0.031 \\
\hline & $(-0.823)$ & $(-2.057)$ & $(-0.650)$ & $(-1.261)$ & $(-4.592)$ & $(-1.628)$ & $(-0.642)$ \\
\hline \multirow[t]{2}{*}{$\%$ For Directors } & $-0.249 *$ & -2.310 & -0.253 & 0.442 & -0.073 & -0.005 & 0.127 \\
\hline & $(-1.732)$ & $(-1.516)$ & $(-1.412)$ & $(0.814)$ & $(-0.945)$ & $(-1.434)$ & $(1.444)$ \\
\hline \multirow[t]{2}{*}{$\log \left(C E O\right.$ Tenure $\left._{t}\right)$} & $-0.040 * * *$ & $-0.446 * *$ & -0.023 & -0.020 & -0.007 & -0.001 & $0.036^{* * *}$ \\
\hline & $(-3.418)$ & $(-2.030)$ & $(-1.132)$ & $(-0.533)$ & $(-1.021)$ & $(-1.221)$ & $(5.549)$ \\
\hline \multirow[t]{2}{*}{$\log \left(\right.$ Revenue $\left._{t}\right)$} & $0.064 * *$ & $0.232 * * *$ & $0.154 * * *$ & $0.090 * * *$ & $0.016 * * *$ & $-0.001 * *$ & $0.022 * * *$ \\
\hline & $(2.417)$ & $(2.844)$ & $(8.230)$ & $(5.933)$ & $(8.811)$ & $(-2.422)$ & $(2.783)$ \\
\hline \multirow[t]{2}{*}{ Book-to-market $t_{t}$} & -0.005 & $-0.558 *$ & $-0.093 * *$ & $-0.211 * * *$ & $-0.038 * * *$ & $0.004 * * *$ & -0.003 \\
\hline & $(-0.180)$ & $(-1.918)$ & $(-2.158)$ & $(-4.432)$ & $(-2.886)$ & $(3.434)$ & $(-0.262)$ \\
\hline \multirow[t]{2}{*}{$R O A_{t}$} & -0.172 & 0.157 & $-0.239^{*}$ & 0.153 & -0.039 & -0.005 & -0.029 \\
\hline & $(-1.021)$ & $(0.095)$ & $(-1.852)$ & $(1.011)$ & $(-0.632)$ & $(-0.850)$ & $(-0.688)$ \\
\hline \multirow[t]{2}{*}{$R O A_{t-1}$} & 0.099 & -2.217 & -0.210 & $-0.465 * * *$ & $-0.106 * *$ & 0.003 & $-0.160 * * *$ \\
\hline & $(0.282)$ & $(-1.404)$ & $(-0.724)$ & $(-3.541)$ & $(-1.993)$ & $(0.516)$ & $(-2.862)$ \\
\hline \multirow[t]{2}{*}{$R O A_{t-2}$} & -0.070 & $1.835^{*}$ & 0.132 & 0.151 & $0.085^{*}$ & -0.006 & 0.031 \\
\hline & $(-0.625)$ & (1.688) & $(0.843)$ & (1.243) & (1.748) & $(-1.091)$ & $(0.460)$ \\
\hline \multirow[t]{2}{*}{ Stock Return ${ }_{t}$} & $0.088 * *$ & 0.317 & $0.264 * * *$ & $0.493 * * *$ & 0.029 & -0.001 & -0.000 \\
\hline & (2.248) & (1.067) & (11.060) & $(6.480)$ & (1.529) & $(-0.925)$ & $(-0.037)$ \\
\hline \multirow[t]{2}{*}{ Stock Return $_{t-1}$} & -0.031 & 0.195 & $0.067 * * *$ & $-0.026^{*}$ & $0.026 * * *$ & -0.001 & -0.014 \\
\hline & $(-1.436)$ & $(0.692)$ & $(2.661)$ & $(-1.948)$ & (2.679) & $(-1.303)$ & $(-0.983)$ \\
\hline \multirow[t]{2}{*}{ Stock Return R-2 $_{2}$} & $-0.027 * *$ & 0.055 & -0.024 & $-0.112 *$ & -0.002 & $0.002 *$ & 0.008 \\
\hline & $(-2.136)$ & $(0.361)$ & $(-0.934)$ & $(-1.782)$ & $(-0.324)$ & (1.889) & $(0.800)$ \\
\hline \multirow[t]{2}{*}{ Dep. Var.t-1 } & $0.620 * * *$ & $0.371 * * *$ & $0.571 * * *$ & $0.820 * * *$ & $0.376 * * *$ & $0.413 * * *$ & \\
\hline & $(13.390)$ & $(10.548)$ & $(19.250)$ & $(30.659)$ & $(16.350)$ & $(8.593)$ & \\
\hline Observations & 2,439 & 2,439 & 2,439 & 2,170 & 2,433 & 980 & 3,045 \\
\hline R-squared & 0.600 & 0.359 & 0.654 & 0.753 & 0.358 & 0.339 & 0.051 \\
\hline
\end{tabular}

This table presents regressions of the one-year ahead (i.e., for the fiscal year following the year of the shareholder meeting) incentive compensation variables on pay plan (\% For Pay Plan) and director (\% For Directors) voting outcomes and determinants of incentive compensation. CEO Turnover $_{t+1}$ is an indicator for taking the value one if the CEO at the time of filing the proxy in year $t+1$ differs from the CEO at the time of the shareholder meeting in year $t$, zero otherwise. Dep. Var $t_{t-1}$ is the lagged value of the respective dependent variable for the fiscal year prior to the shareholder vote. The remaining variables are as defined in the caption to Panel A of Table I. Industry (two-digit SIC) and year indicators are included but unreported. ***,**, and $*$ denote statistical significance (two-sided) at the $1 \%, 5 \%$, and $10 \%$ levels, respectively. Standard errors are calculated based on two-way clustering by firm and year. 


\section{Table III (cont'd)}

\section{Panel C: Two Year-Ahead Compensation Variables}

\begin{tabular}{|c|c|c|c|c|c|c|c|}
\hline & $\begin{array}{c}\text { Cash } \\
\text { Comp }_{t+2}\end{array}$ & $\begin{array}{l}\text { Option } \\
\text { Comp }_{t+2}\end{array}$ & $\begin{array}{c}\text { Total } \\
\text { Comp }_{t+2}\end{array}$ & $\begin{array}{l}\text { Portfolio } \\
\text { Delta }_{t+2}\end{array}$ & $\begin{array}{l}\text { Comp } \\
\text { Mix }_{t+2}\end{array}$ & $\begin{array}{c}\text { Options } \\
\text { Granted }_{t+2}\end{array}$ & $\begin{array}{c}\text { CEO } \\
\text { Turnover }_{t+2}\end{array}$ \\
\hline \multirow[t]{2}{*}{$\%$ For Pay Plan } & 0.007 & 0.978 & 0.104 & 0.080 & -0.014 & 0.000 & 0.103 \\
\hline & $(0.074)$ & (1.036) & (1.069) & $(0.734)$ & $(-0.378)$ & $(0.022)$ & (1.401) \\
\hline \multirow[t]{2}{*}{$\%$ For Directors } & -0.087 & -0.718 & 0.222 & -0.149 & -0.003 & $0.022 * * *$ & 0.295 \\
\hline & $(-0.299)$ & $(-0.246)$ & $(0.449)$ & $(-0.630)$ & $(-0.023)$ & $(4.705)$ & (1.604) \\
\hline \multirow[t]{2}{*}{$\log \left(C E O\right.$ Tenure $\left._{t}\right)$} & -0.046 & $-0.539 * *$ & $-0.052 *$ & $-0.094 * *$ & -0.009 & -0.001 & $0.039^{*}$ \\
\hline & $(-1.276)$ & $(-2.184)$ & $(-1.947)$ & $(-2.460)$ & $(-0.888)$ & $(-1.141)$ & (1.923) \\
\hline \multirow[t]{2}{*}{$\log _{\left(\text {Revenue }_{t}\right)}$} & $0.079 *$ & $0.319 * * *$ & $0.190 * * *$ & $0.119 * * *$ & $0.017 * * *$ & $-0.002 * *$ & $0.034 * * *$ \\
\hline & (1.895) & (2.674) & (5.612) & (4.779) & (3.446) & $(-2.494)$ & (3.039) \\
\hline \multirow[t]{2}{*}{ Book-to-market ${ }_{t}$} & 0.055 & -0.366 & $-0.209 * * *$ & -0.224 & $-0.067 * * *$ & -0.001 & 0.010 \\
\hline & $(0.478)$ & $(-0.828)$ & $(-2.770)$ & $(-1.634)$ & $(-2.865)$ & $(-0.523)$ & $(0.196)$ \\
\hline \multirow[t]{2}{*}{$R O A_{t}$} & $-0.452 * *$ & -1.579 & $-0.505^{* * *}$ & $-0.372 * *$ & $-0.109 * *$ & $0.010 * * *$ & -0.023 \\
\hline & $(-2.070)$ & $(-1.133)$ & $(-2.762)$ & $(-2.162)$ & $(-2.459)$ & $(3.374)$ & $(-0.500)$ \\
\hline \multirow[t]{2}{*}{$R O A_{t-1}$} & 0.104 & -1.569 & -0.079 & -0.125 & -0.046 & -0.001 & -0.150 \\
\hline & $(0.333)$ & $(-0.985)$ & $(-0.207)$ & $(-0.812)$ & $(-0.960)$ & $(-0.068)$ & $(-1.032)$ \\
\hline \multirow[t]{2}{*}{$R O A_{t-2}$} & -0.019 & 1.266 & $0.043 * * *$ & 0.096 & $0.045^{*}$ & $-0.017 * * *$ & -0.082 \\
\hline & $(-0.260)$ & $(1.474)$ & $(4.509)$ & $(0.562)$ & $(1.713)$ & $(-2.650)$ & $(-0.695)$ \\
\hline \multirow[t]{2}{*}{ Stock Return $_{t}$} & 0.031 & 0.036 & $0.132 *$ & $0.447 * * *$ & 0.012 & -0.001 & $-0.037 *$ \\
\hline & $(1.402)$ & $(0.163)$ & $(1.924)$ & $(4.847)$ & $(1.274)$ & $(-0.561)$ & $(-1.647)$ \\
\hline \multirow[t]{2}{*}{ Stock Return R-1 $_{1}$} & -0.045 & 0.334 & 0.055 & -0.085 & $0.022^{*}$ & 0.001 & -0.006 \\
\hline & $(-1.534)$ & $(1.461)$ & $(1.327)$ & $(-1.202)$ & $(1.771)$ & $(0.125)$ & $(-0.343)$ \\
\hline \multirow[t]{2}{*}{ Stock Return $_{t-2}$} & -0.017 & $-0.381 * *$ & -0.034 & -0.042 & -0.004 & -0.001 & 0.012 \\
\hline & $(-0.707)$ & $(-2.325)$ & $(-0.730)$ & $(-1.086)$ & $(-0.441)$ & $(-0.748)$ & $(0.573)$ \\
\hline \multirow[t]{2}{*}{ Dep. $\operatorname{Var}_{\cdot t-1}$} & $0.504 * * *$ & $0.276 * * *$ & $0.469 * * *$ & $0.784 * * *$ & $0.325 * * *$ & $0.285 * * *$ & -- \\
\hline & (6.993) & (8.238) & (11.140) & $(15.576)$ & (11.645) & (5.609) & -- \\
\hline Observations & 1,162 & 1,162 & 1,162 & 1,027 & 1,160 & 325 & 1,713 \\
\hline R-squared & 0.549 & 0.366 & 0.595 & 0.714 & 0.365 & 0.459 & 0.088 \\
\hline
\end{tabular}

This table presents regressions of the two year-ahead (i.e., for the second fiscal year following the year of the shareholder meeting) incentive compensation variables on pay plan (\% For Pay Plan) and director (\% For Directors) voting outcomes and determinants of incentive compensation. CEO Turnover $_{t+2}$ is an indicator for taking the value one if the CEO at the time of filing the proxy in year $t+2$ differs from the CEO at the time of the shareholder meeting in year $t$, zero otherwise Dep. Var $r_{t-1}$ is the lagged value of the respective dependent variable for the fiscal year prior to the shareholder vote. The remaining variables are as defined in the caption to Panel A of Table I. Industry (two-digit SIC) and year indicators are included but unreported. ***, **, and $*$ denote statistical significance (two-sided) at the 1\%,5\%, and $10 \%$ levels, respectively. Standard errors are calculated based on two-way clustering by firm and year. 


\section{Table IV \\ Effect of Shareholder Voting: Equity-based Compensation Plans Instrumental Variables Analysis, One Year-Ahead Compensation Variables}

\begin{tabular}{|c|c|c|c|c|c|c|c|}
\hline & $\begin{array}{c}\text { Cash } \\
\text { Comp }_{t+1}\end{array}$ & $\begin{array}{l}\text { Option } \\
\text { Comp }_{t+1}\end{array}$ & $\begin{array}{c}\text { Total } \\
\text { Comp }_{t+1}\end{array}$ & $\begin{array}{c}\text { Portfolio } \\
\text { Delta }_{t+1}\end{array}$ & $\begin{array}{l}\text { Comp } \\
\text { Mix }_{t+1}\end{array}$ & $\begin{array}{c}\text { Options } \\
\text { Granted }_{t+1}\end{array}$ & $\begin{array}{c}\text { CEO } \\
\text { Turnover }_{t+1}\end{array}$ \\
\hline \multirow{2}{*}{ \% For Pay Plan } & 0.141 & 0.585 & -0.088 & $-0.241 * * *$ & $-0.115 * * *$ & -0.004 & 0.016 \\
\hline & $(1.029)$ & $(0.457)$ & $(-0.505)$ & $(-2.781)$ & $(-4.443)$ & $(-0.576)$ & $(0.150)$ \\
\hline \multirow{2}{*}{$\log \left(C E O\right.$ Tenure $\left._{t}\right)$} & $-0.033 * * *$ & $-0.470 * *$ & $-0.030 *$ & -0.029 & $-0.011^{*}$ & -0.002 & $0.036^{* * *} *$ \\
\hline & $(-3.334)$ & $(-2.301)$ & $(-1.796)$ & $(-0.949)$ & $(-1.881)$ & $(-1.591)$ & $(5.854)$ \\
\hline \multirow[t]{2}{*}{$\log \left(\right.$ Revenue $\left._{t}\right)$} & $0.063 * * *$ & $0.229 * * *$ & $0.158 * * *$ & $0.091 * * *$ & $0.016^{* * *}$ & $-0.001 * * *$ & $0.022 * * *$ \\
\hline & (2.874) & (2.997) & $(9.332)$ & $(7.199)$ & $(8.709)$ & $(-4.653)$ & $(3.336)$ \\
\hline \multirow{2}{*}{ Book-to-market ${ }_{t}$} & 0.036 & $-0.495 * *$ & $-0.072 * * *$ & $-0.194 * * *$ & $-0.035^{* * *}$ & $0.003 * *$ & -0.004 \\
\hline & (1.524) & $(-2.077)$ & $(-2.986)$ & $(-4.079)$ & $(-4.140)$ & $(2.048)$ & $(-0.336)$ \\
\hline \multirow[t]{2}{*}{$R O A_{t}$} & -0.126 & 0.405 & $-0.237 * *$ & 0.127 & -0.037 & -0.003 & $-0.061 *$ \\
\hline & $(-1.002)$ & $(0.265)$ & $(-2.165)$ & $(0.946)$ & $(-0.644)$ & $(-0.527)$ & $(-1.649)$ \\
\hline \multirow[t]{2}{*}{$R O A_{t-1}$} & 0.143 & $-2.999 * *$ & -0.260 & $-0.423 * * *$ & $-0.136 * * *$ & -0.004 & $-0.145^{* *}$ \\
\hline & $(0.536)$ & $(-2.049)$ & $(-1.315)$ & $(-3.069)$ & $(-2.750)$ & $(-0.713)$ & $(-2.567)$ \\
\hline \multirow[t]{2}{*}{$R O A_{t-2}$} & -0.118 & $2.296^{* *}$ & 0.161 & 0.119 & $0.104 * *$ & -0.001 & 0.018 \\
\hline & $(-1.233)$ & $(2.427)$ & $(1.476)$ & $(1.426)$ & $(2.445)$ & $(-0.172)$ & $(0.247)$ \\
\hline \multirow[t]{2}{*}{ Stock Return $_{t}$} & $0.104 * * *$ & 0.333 & $0.280 * * *$ & $0.502 * * *$ & $0.032 * *$ & -0.002 & 0.001 \\
\hline & (3.109) & $(1.469)$ & $(10.444)$ & $(7.246)$ & $(2.505)$ & $(-1.635)$ & $(0.130)$ \\
\hline \multirow[t]{2}{*}{ Stock Return $_{t-1}$} & -0.026 & 0.275 & $0.067 * *$ & $-0.026 * * *$ & $0.029 * * *$ & $-0.002 *$ & -0.010 \\
\hline & $(-1.498)$ & $(1.125)$ & $(2.425)$ & $(-2.660)$ & $(3.608)$ & $(-1.855)$ & $(-1.081)$ \\
\hline \multirow[t]{2}{*}{ Stock Return $_{t-2}$} & $-0.032 * * *$ & 0.094 & -0.030 & $-0.111 * *$ & -0.002 & $0.002 * *$ & 0.007 \\
\hline & $(-2.615)$ & $(0.690)$ & $(-1.227)$ & $(-2.126)$ & $(-0.331)$ & $(2.512)$ & $(0.857)$ \\
\hline \multirow[t]{2}{*}{ Dep. Var $_{\cdot t-1}$} & $0.627 * * *$ & $0.374 * * *$ & $0.568 * * *$ & $0.822 * * *$ & $0.382 * * *$ & $0.403 * * *$ & -- \\
\hline & $(15.985)$ & $(11.388)$ & $(22.162)$ & $(38.212)$ & $(17.524)$ & $(25.616)$ & -- \\
\hline Observations & 2,568 & 2,568 & 2,568 & 2,285 & 2,562 & 1,000 & 3,205 \\
\hline R-squared & 0.600 & 0.347 & 0.650 & 0.757 & 0.350 & 0.322 & 0.049 \\
\hline
\end{tabular}

This table presents regressions of the one-year ahead (i.e., for the fiscal year following the year of the shareholder meeting) incentive compensation variables on shareholder support for the pay plan (\% For Pay Plan) and determinants of incentive compensation using an indicator for ISS voting recommendation being "for" the pay plan (ISS For Pay Plan) as an instrument for \% For Pay Plan. CEO Turnover ${ }_{t+1}$ is an indicator for taking the value one if the CEO at the time of filing the proxy in year $t+1$ differs from the CEO at the time of the shareholder meeting in year $t$, zero otherwise. Dep. $V a r_{t-1}$ is the lagged value of the respective dependent variable for the fiscal year prior to the shareholder vote. The remaining variables are as defined in the caption to Panel A of Table I. Industry (two-digit SIC) and year indicators are included but unreported. ***, **, and * denote statistical significance (two-sided) at the $1 \%, 5 \%$, and $10 \%$ levels, respectively. Standard errors are calculated based on two-way clustering by firm and year. 


\section{Table V \\ Regression Discontinuity}

Panel A: One Year-Ahead Excess Compensation

\begin{tabular}{|c|c|c|c|c|c|c|}
\hline & \multicolumn{2}{|c|}{ Bandwidth 50} & \multicolumn{2}{|c|}{ Bandwidth 100} & \multicolumn{2}{|c|}{ Bandwidth 200} \\
\hline & Coef. & $t$-stat. & Coef. & $t$-stat. & Coef. & $t$-stat. \\
\hline Excess $\log \left(\right.$ Cash Comp $\left._{t+1}\right)$ & -0.047 & $(-0.354)$ & -0.060 & $(-0.300)$ & 0.002 & $(0.020)$ \\
\hline Excess log $_{\left.\text {Option Grant } \text { Value }_{t+1}\right)}$ & -0.686 & $(-0.442)$ & -0.071 & $(-0.032)$ & -0.815 & $(-0.689)$ \\
\hline Excess $\log \left(\right.$ Total $_{\text {Comp }}$ tr+ $\left._{1}\right)$ & -0.293 & $(-1.622)$ & -0.412 & $(-1.645)$ & -0.172 & $(-1.227)$ \\
\hline Excess $\log \left(\right.$ Portfolio Delta $\left.t_{t+1}\right)$ & 0.086 & $(0.601)$ & 0.091 & $(0.498)$ & 0.067 & $(0.507)$ \\
\hline Excess Comp Mix $x_{t+1}$ & -0.083 & $(-1.500)$ & $-0.142 * *$ & $(-1.961)$ & -0.050 & $(-1.097)$ \\
\hline Excess Options Granted $_{t+1}$ & -0.008 & $(-1.001)$ & -0.011 & $(-0.981)$ & -0.008 & $(-1.269)$ \\
\hline CEO Turnover Thl $_{t+1}$ & $0.098 *$ & $(1.926)$ & 0.073 & (1.097) & $0.117^{* *}$ & $(2.503)$ \\
\hline
\end{tabular}

This table presents the results of local polynomial regressions on either side of the $50 \%$ discontinuity in the percentage of votes in favor of the pay plan (\% For Pay Plan). The compensation-related dependent variables are excess one-year ahead (i.e., for the fiscal year following the year of the shareholder meeting) variables defined as the residuals from the regressions in Table IV, Panel B. CEO Turnover $r_{t+1}$ is an indicator for taking the value one if the CEO at the time of filing the proxy in year $t+1$ differs from the CEO at the time of the shareholder meeting in year $t$, zero otherwise. Bandwidths of $50 \%$, $100 \%$, and $200 \%$ of the default are considered and a triangular kernel is used for the estimation.

Panel B: Two Year-Ahead Excess Compensation

\begin{tabular}{|c|c|c|c|c|c|c|}
\hline & \multicolumn{2}{|c|}{ Bandwidth 50} & \multicolumn{2}{|c|}{ Bandwidth 100} & \multicolumn{2}{|c|}{ Bandwidth 200} \\
\hline & Coef. & $t$-stat. & Coef. & $t$-stat. & Coef. & $t$-stat. \\
\hline Excess log $\left(\right.$ Cash Comp $\left.{ }_{t+2}\right)$ & $0.185^{*}$ & $(1.690)$ & 0.121 & $(0.899)$ & 0.123 & $(1.341)$ \\
\hline Excess $\log \left(\right.$ Option Grant Value $\left._{t+2}\right)$ & $3.182 *$ & $(1.703)$ & 3.917 & $(1.549)$ & 1.080 & $(0.764)$ \\
\hline Excess $\log \left(\right.$ Total Comp $\left._{t+2}\right)$ & $-0.293 *$ & $(-1.811)$ & -0.198 & $(-0.934)$ & $-0.234^{*}$ & $(-1.727)$ \\
\hline Excess log $\left(\right.$ Portfolio Delta $\left._{t+2}\right)$ & $1.635^{* *}$ & $(1.982)$ & $1.742^{*}$ & $(1.740)$ & $1.595^{* *}$ & $(2.221)$ \\
\hline Excess Comp Mix $x_{t+2}$ & -0.009 & $(-0.134)$ & 0.031 & $(0.367)$ & -0.022 & $(-0.400)$ \\
\hline${\text { Excess Options } \text { Granted }_{t+2}}$ & 0.006 & $(0.785)$ & $0.013 * * *$ & $(4.897)$ & -0.000 & $(-0.008)$ \\
\hline CEO Turnover ${ }_{t+2}$ & 0.069 & $(0.738)$ & -0.028 & $(-0.215)$ & 0.078 & $(0.987)$ \\
\hline
\end{tabular}

This table presents the results of local polynomial regressions on either side of the $50 \%$ discontinuity in the percentage of votes in favor of the pay plan (\% For Pay Plan). The compensation-related dependent variables are excess two-year ahead (i.e., for the second fiscal year following the year of the shareholder meeting) variables defined as the residuals from the regressions in Table IV, Panel C. CEO Turnover Th $_{t+2}$ is an indicator for taking the value one if the CEO at the time of filing the proxy in year $t+2$ differs from the CEO at the time of the shareholder meeting in year $t$, zero otherwise. Bandwidths of 50\%, 100\%, and 200\% of the default are considered and a triangular kernel is used for the estimation. 
Table VI

Regression Discontinuity

\section{Equity-based Pay Plan Proposals in Subsequent Year}

\begin{tabular}{|c|c|c|c|c|c|c|}
\hline & \multicolumn{2}{|c|}{ Bandwidth 50} & \multicolumn{2}{|c|}{ Bandwidth 100} & \multicolumn{2}{|c|}{ Bandwidth 200} \\
\hline & Coef. & $t$-stat. & Coef. & $t$-stat. & Coef. & $t$-stat. \\
\hline Proposal $_{t+1}$ & $-0.559 * * *$ & $(-4.697)$ & $-0.578 * * *$ & $(-3.465)$ & $-0.416 * * *$ & $(-4.438)$ \\
\hline$\%$ For Pay Plan Pl+1 $_{t}$ & 0.020 & $(0.587)$ & 0.000 & $(0.001)$ & 0.015 & $(0.508)$ \\
\hline Shares Requested $_{t+1}$ & $-0.025 * * *$ & $(-3.015)$ & $-0.027 * * *$ & $(-2.704)$ & $-0.020 * * *$ & $(-3.124)$ \\
\hline Shares Approved $_{t+1}$ & $0.020 * *$ & $(2.232)$ & 0.012 & $(1.107)$ & 0.015 & $(1.266)$ \\
\hline
\end{tabular}

This table presents the results of local polynomial regressions on either side of the $50 \%$ discontinuity in the percentage of votes in favor of the pay plan (\% For Pay Plan). Proposal $t_{t+1}$ is an indicator variable for the firm requesting shares in the year after the initial request. \% For Pay Plan P $_{t+1}$ is the level of shareholder support for equity-based pay plans submitted in year $\mathrm{t}+1$. Shares Requested is the number of shares requested by the pay plan proposed in $t+1$ scaled by the number of shares outstanding. Shares Approved $_{t+1}$ equals the sum of shares approved in $t$ and shares requested in $t+1$. Bandwidths of 50\%, 100\%, and $200 \%$ of the default are considered and a triangular kernel is used for the estimation. 
Table VII

Effect of Shareholder Voting: Director Elections

Panel A: Ordinary Least Squares Analysis

\begin{tabular}{|c|c|c|c|c|c|c|c|}
\hline & $\begin{array}{c}\text { Cash } \\
\text { Comp }_{t+1}\end{array}$ & $\begin{array}{l}\text { Option } \\
\text { Comp }_{t+1}\end{array}$ & $\begin{array}{c}\text { Total } \\
\text { Comp }_{t+1}\end{array}$ & $\begin{array}{c}\text { Portfolio } \\
\text { Delta }_{t+1}\end{array}$ & $\begin{array}{l}\text { Comp } \\
\text { Mix }_{t+1}\end{array}$ & $\begin{array}{c}\text { Options } \\
\text { Granted }_{t+1}\end{array}$ & $\begin{array}{c}\text { CEO } \\
\text { Turnover }_{t+1}\end{array}$ \\
\hline \multirow[t]{2}{*}{$\%$ For Director } & -0.062 & -0.070 & -0.050 & 0.168 & -0.022 & $-0.004 * * *$ & $-0.015 * * *$ \\
\hline & $(-1.134)$ & $(-0.615)$ & $(-0.623)$ & $(0.906)$ & $(-0.623)$ & $(-4.348)$ & $(-3.252)$ \\
\hline \multirow[t]{2}{*}{$\log \left(C E O\right.$ Tenure $\left._{t}\right)$} & $-0.037 * * *$ & $-0.311 * *$ & $-0.023^{*}$ & -0.009 & $-0.013 * * *$ & 0.000 & 0.002 \\
\hline & $(-4.451)$ & $(-2.553)$ & $(-1.724)$ & $(-0.338)$ & $(-3.251)$ & $(0.260)$ & $(0.904)$ \\
\hline \multirow[t]{2}{*}{$\log \left(\right.$ Revenue $\left._{t}\right)$} & $0.061 * * *$ & $0.361 * * *$ & $0.170 * * *$ & $0.105 * * *$ & $0.023 * * *$ & $-0.000 * *$ & 0.001 \\
\hline & $(4.400)$ & $(3.259)$ & $(8.265)$ & $(6.025)$ & $(4.314)$ & $(-2.515)$ & $(1.396)$ \\
\hline \multirow[t]{2}{*}{ Book-to-market $t_{t}$} & $-0.027 * *$ & -0.503 & $-0.080 * * *$ & $-0.247 * * *$ & $-0.030 * *$ & $-0.001 * * *$ & 0.001 \\
\hline & $(-2.009)$ & $(-1.326)$ & $(-2.736)$ & $(-3.898)$ & $(-2.246)$ & $(-5.678)$ & $(0.735)$ \\
\hline \multirow{2}{*}{$R O A_{t}$} & -0.023 & 0.370 & -0.093 & 0.064 & -0.005 & -0.004 & -0.003 \\
\hline & $(0.000)$ & $(0.471)$ & $(-0.824)$ & $(0.323)$ & $(-0.183)$ & $(-1.282)$ & $(-0.367)$ \\
\hline \multirow[t]{2}{*}{$R O A_{t-1}$} & -0.117 & $-1.591^{*}$ & $-0.231 *$ & $-0.219 *$ & -0.050 & 0.000 & -0.014 \\
\hline & $(-1.343)$ & $(-1.681)$ & $(-1.767)$ & $(-1.727)$ & $(-1.184)$ & $(0.091)$ & $(-1.121)$ \\
\hline \multirow[t]{2}{*}{$R O A_{t-2}$} & 0.064 & 0.232 & -0.048 & 0.310 & -0.054 & $-0.006^{* * *}$ & -0.018 \\
\hline & $(0.663)$ & $(0.335)$ & $(-0.878)$ & $(1.127)$ & $(-1.551)$ & $(-2.638)$ & $(-1.197)$ \\
\hline \multirow[t]{2}{*}{ Stock Return $_{t}$} & $0.101 * * *$ & $0.469^{*}$ & $0.237 * * *$ & $0.488 * * *$ & $0.020 * *$ & $-0.002 * * *$ & 0.001 \\
\hline & $(2.779)$ & $(1.765)$ & (7.483) & $(6.823)$ & $(2.199)$ & $(-2.850)$ & $(0.295)$ \\
\hline \multirow[t]{2}{*}{ Stock Return $_{t-1}$} & $-0.031^{*}$ & 0.138 & $0.045^{* * *}$ & $-0.078 * *$ & $0.012 * *$ & $-0.001 *$ & -0.000 \\
\hline & $(-1.925)$ & $(1.197)$ & (3.489) & $(-2.101)$ & $(2.192)$ & $(-1.891)$ & $(-0.137)$ \\
\hline \multirow[t]{2}{*}{ Stock Return $_{t-2}$} & $-0.036 * * *$ & 0.050 & $-0.024 * * *$ & $-0.135^{* * *}$ & 0.000 & 0.000 & $0.003 * *$ \\
\hline & $(-3.490)$ & $(0.545)$ & $(-3.080)$ & $(-3.283)$ & $(0.045)$ & $(0.761)$ & (2.006) \\
\hline \multirow[t]{2}{*}{ Dep. Var ${ }_{t-1}$} & $0.643 * * *$ & $0.400 * * *$ & $0.580 * * *$ & $0.830 * * *$ & $0.355^{* * *}$ & $0.359 * * *$ & -- \\
\hline & $(16.027)$ & $(7.011)$ & $(23.755)$ & $(21.903)$ & $(11.680)$ & $(11.692)$ & -- \\
\hline Observations & 60,507 & 60,507 & 60,507 & 55,129 & 60,311 & 33,966 & 73,522 \\
\hline R-squared & 0.616 & 0.418 & 0.702 & 0.574 & 0.344 & 0.291 & 0.010 \\
\hline
\end{tabular}

This table presents regressions of the one-year ahead (i.e., for the fiscal year following the year of the shareholder meeting) incentive compensation variables on shareholder support for directors (\% For Director) and determinants of incentive compensation for the sample of all director elections. CEO Turnover ${ }_{t+1}$ is an indicator for taking the value one if the CEO at the time of filing the proxy in year $t+1$ differs from the CEO at the time of the shareholder meeting in year $t$, zero otherwise. Dep. $V a r_{t-1}$ is the lagged value of the respective dependent variable for the fiscal year prior to the shareholder vote. The remaining variables are as defined in the caption to Panel A of Table I. Industry (two-digit SIC) and year indicators are included but unreported. $* * *, * *$, and $*$ denote statistical significance (two-sided) at the $1 \%, 5 \%$, and $10 \%$ levels, respectively. Standard errors are calculated based on two-way clustering by firm and year. 
Table VII (cont'd)

Effect of Shareholder Voting: Director Elections

Panel B: Instrumental Variables Analysis

\begin{tabular}{|c|c|c|c|c|c|c|c|}
\hline & $\begin{array}{c}\text { Cash } \\
\text { Comp }_{t+1}\end{array}$ & $\begin{array}{c}\text { Option } \\
\text { Comp }_{t+1}\end{array}$ & $\begin{array}{c}\text { Total } \\
\text { Comp }_{t+1}\end{array}$ & $\begin{array}{c}\text { Portfolio }_{\text {Delta }}++1 \\
\end{array}$ & $\begin{array}{l}\text { Comp } \\
\text { Mix }_{t+1} \\
\end{array}$ & $\begin{array}{c}\text { Options } \\
\text { Granted }_{t+1}\end{array}$ & $\begin{array}{c}\text { CEO } \\
\text { Turnover }_{t+1}\end{array}$ \\
\hline \multirow[t]{2}{*}{$\%$ For Director } & 0.116 & $2.320 * *$ & $0.240 * * *$ & $0.350 *$ & $0.096^{* * *}$ & 0.000 & 0.020 \\
\hline & $(0.954)$ & $(2.190)$ & $(2.592)$ & (1.738) & $(2.853)$ & $(0.280)$ & $(1.525)$ \\
\hline \multirow{2}{*}{$\log \left(C E O\right.$ Tenure $\left._{t}\right)$} & $-0.036 * * *$ & $-0.306 * * *$ & $-0.022 *$ & -0.009 & $-0.013 * * *$ & 0.000 & 0.002 \\
\hline & $(-4.601)$ & $(-2.688)$ & $(-1.751)$ & $(-0.355)$ & $(-3.392)$ & $(0.308)$ & $(0.947)$ \\
\hline \multirow[t]{2}{*}{$\log _{\left(\text {Revenue }_{t}\right)}$} & $0.061 * * *$ & $0.362 * * *$ & $0.170^{* * *}$ & $0.104 * * *$ & $0.023 * * *$ & $-0.000^{* * *}$ & 0.001 \\
\hline & $(4.636)$ & $(3.522)$ & $(8.858)$ & $(6.395)$ & $(4.642)$ & $(-2.771)$ & $(1.430)$ \\
\hline \multirow[t]{2}{*}{ Book-to-market $t_{t}$} & $-0.026^{* *}$ & -0.482 & $-0.078 * * *$ & $-0.246^{* * *}$ & $-0.029 * *$ & $-0.001 * * *$ & 0.002 \\
\hline & $(-2.084)$ & $(-1.373)$ & $(-2.895)$ & $(-4.155)$ & $(-2.374)$ & $(-5.716)$ & $(1.001)$ \\
\hline \multirow[t]{2}{*}{$R O A_{t}$} & -0.029 & 0.318 & -0.100 & 0.062 & -0.007 & -0.004 & -0.003 \\
\hline & $(0.000)$ & $(0.428)$ & $(-0.938)$ & $(0.341)$ & $(-0.284)$ & $(-1.429)$ & $(-0.328)$ \\
\hline \multirow[t]{2}{*}{$R O A_{t-1}$} & -0.119 & $-1.608^{*}$ & $-0.234 *$ & $-0.219^{*}$ & -0.051 & 0.001 & -0.014 \\
\hline & $(-1.527)$ & $(-1.857)$ & $(-1.949)$ & $(-1.855)$ & $(-1.314)$ & $(0.111)$ & $(-1.216)$ \\
\hline \multirow[t]{2}{*}{$R O A_{t-2}$} & 0.067 & 0.254 & -0.044 & 0.311 & -0.053 & $-0.006^{* * *}$ & -0.018 \\
\hline & $(0.751)$ & $(0.396)$ & $(-0.843)$ & $(1.218)$ & $(-1.627)$ & $(-2.891)$ & $(-1.290)$ \\
\hline \multirow[t]{2}{*}{ Stock Return $_{t}$} & $0.101 * * *$ & $0.463^{*}$ & $0.237 * * *$ & $0.489 * * *$ & $0.020 * *$ & $-0.003^{* * *}$ & 0.001 \\
\hline & (3.022) & (1.934) & $(8.236)$ & (7.377) & $(2.367)$ & $(-3.108)$ & $(0.275)$ \\
\hline \multirow[t]{2}{*}{ Stock Return $_{t-1}$} & $-0.031 * *$ & 0.147 & $0.045^{* * *}$ & $-0.077 * *$ & $0.012 * *$ & $-0.001 * *$ & -0.000 \\
\hline & $(-2.090)$ & $(1.391)$ & $(3.738)$ & $(-2.222)$ & $(2.524)$ & $(-2.046)$ & $(-0.097)$ \\
\hline \multirow[t]{2}{*}{ Stock Return $_{t-2}$} & $-0.036 * * *$ & 0.052 & $-0.024 * * *$ & $-0.136 * * *$ & 0.000 & 0.000 & $0.003 * *$ \\
\hline & $(-3.787)$ & $(0.611)$ & $(-3.307)$ & $(-3.608)$ & $(0.068)$ & $(0.857)$ & $(2.122)$ \\
\hline \multirow[t]{2}{*}{ Dep. Var $_{t-1}$} & $0.643 * * *$ & $0.401 * * *$ & $0.581 * * *$ & $0.830 * * *$ & $0.356^{* * *}$ & $0.360 * * *$ & -- \\
\hline & $(16.829)$ & $(7.532)$ & $(25.271)$ & $(23.519)$ & $(12.528)$ & $(12.826)$ & -- \\
\hline Observations & 60,447 & 60,447 & 60,447 & 55,071 & 60,251 & 33,964 & 73,452 \\
\hline
\end{tabular}

This table presents regressions of contemporaneous (i.e., for the fiscal year that includes the shareholder meeting) incentive compensation variables on shareholder support for directors (\% For Directors) and determinants of incentive compensation for the sample of all director elections using an indicator for ISS voting recommendation being "for" the director (ISS For Director) as an instrument for \% For Director. CEO Turnover ${ }_{t+1}$ is an indicator for taking the value one if the CEO at the time of filing the proxy in year $t+1$ differs from the CEO at the time of the shareholder meeting in year $t$, zero otherwise. Dep. Var $r_{t-1}$ is the lagged value of the respective dependent variable for the fiscal year prior to the shareholder vote. The remaining variables are as defined in the caption to Panel A of Table I. Industry (two-digit SIC) and year indicators are included but unreported. ***, **, and * denote statistical significance (two-sided) at the 1\%,5\%, and 10\% levels, respectively. Standard errors are calculated based on two-way clustering by firm and year. 